BULLETIN Bulletin hispanique

HispaniQuE Université Michel de Montaigne Bordeaux

114-1 | 2012

Varia

\title{
Agencias tridentinas en la Salamanca filipina
}

El caso Sánchez de las Brozas, 1584-1600

Santiago Francisco Peña

\section{(2) OpenEdition}

Journals

Edición electrónica

URL: http://journals.openedition.org/bulletinhispanique/1654

DOI: 10.4000/bulletinhispanique.1654

ISSN: 1775-3821

Editor

Presses universitaires de Bordeaux

\section{Edición impresa}

Fecha de publicación: 1 junio 2012

Paginación: 41-67

ISBN: 978-2-86781-812-7

ISSN: 0007-4640

Referencia electrónica

Santiago Francisco Peña, « Agencias tridentinas en la Salamanca filipina », Bulletin hispanique [En línea], 114-1 | 2012, Publicado el 01 junio 2015, consultado el 26 abril 2019. URL : http://

journals.openedition.org/bulletinhispanique/1654; DOI : 10.4000/bulletinhispanique.1654 


\title{
Agencias tridentinas en la Salamanca filipina. El caso Sánchez de las Brozas, 1584-1600
}

\author{
Santiago Francisco Peña \\ Universidad de Buenos Aires - Argentina
}

Les procès inquisitoriaux perpétrés entre 1584 et 1600 contre Sánchez de las Brozas, professeur à l'Université de Salamanque, semblent illustrer, au sein du catholicisme de la Renaissance, une polémique autour de la libre interprétation du christianisme. Mais penser la défaite humaniste à l'Époque moderne c'est aussi penser la violence judiciaire, monopole d'un État capable de définir les frontières de l'orthodoxie.

Los procesos inquisitoriales perpetrados entre 1584 y 1600 contra Sánchez de las Brozas, profesor de la Universidad de Salamanca, aparecen como la materialización de una polémica al interior del catolicismo renacentista en torno de la libre interpretación del cristianismo. Pero pensar la caida del humanismo durante la Edad Moderna es también pensar la violencia judicial, monopolio de un Estado capaz de definir las fronteras de la ortodoxia.

The inquisitorial trials held against Sanchez de las Brozas, Professor at the University of Salamanca, between 1584 and 1600, seem to illustrate, within the Renaissance Roman Catholicism, a controversy around the free interpretation of Christianism. Yet, to think in our times the humanist defeat is also to think judicial violence - the monopole of a State able to define the borders of orthodoxy.

Mots-clés : Sánchez de las Brozas, Humanisme, Contre-réforme, Inquisition espagnole.

I. Corría el año 1584 cuando el maestro Francisco Sánchez de las Brozas (1523-1600) optó por responder a las inquietudes teológicas de sus estudiantes con temeraria sinceridad. Así, desató un escándalo al interior de la Universidad de Salamanca y puso en riesgo su lugar privilegiado en el fuero universitario y, por supuesto, su propia vida. Según se dijo, el sexagenario profesor utilizaba ese espacio de clases para dar rienda suelta a su elocuencia o, en opinión de 
Juan Collado, uno de sus alumnos, «hablaba con libertad ${ }^{1}$. Habría declarado, entre otras imprudencias, que aquellos que adoraban las imágenes de los santos y se hincaban ante ellos eran «bobos» y que directamente «no había de haber imágenes», que Jesús no fue parido en el pesebre, que los Reyes Magos no habían sido probablemente reyes ni habrían ido a adorar a Cristo trece días después de su nacimiento, sino hasta dos años después. Alguno le atribuyó un exabrupto espectacular: "imierda para Santo Tomás!». Como si hiciera falta, aseguró que los teólogos «no saben nada».

Estas tímidas proposiciones, malsonantes algunas, otras directamente heréticas, llegaron a los oídos de un tal Cristóbal Rodríguez, comisario de la Inquisición, quien elevó el caso al tribunal competente, asentado en Valladolid. Los inquisidores, advertidos, ordenaron la correspondiente carrera testimonial ${ }^{2}$. Los testigos, tal como ocurría cuando la Inquisición metía sus narices en los conflictos internos de la universidad, provendrían de la "gente de manteo y bonete»: sus propios estudiantes, un clérigo, un teólogo, un jurista. En definitiva, buena parte del circunspecto mundo universitario hizo causa común con el Santo Oficio ${ }^{3}$. También es cierto que hubo testimonios favorables al profesor, pero estos - por motivos que intentarán ser develados a lo largo de este artículo- no tuvieron un peso determinante en la marcha del proceso ${ }^{4}$.

1. Sobre el método pedagógico del Brocense, cf. C. Chaparro Gómez, «El Brocense, hoy: su vigencia en el ámbito de la filología», Cuadernos de Filología Clásica. Estudios Latinos, $\mathrm{n}^{\circ} 21$, 2001, p. 182.

2. La fuente en cuestión se encuentra en B. N. Ms. 12745. Aquí se utiliza la edición de A. Tovar y M. De La Pinta Llorente, eds., Procesos inquisitoriales contra Francisco Sánchez de las Brozas, Madrid, Instituto Antonio de Nebrija, 1941.

3. En un reciente trabajo, el profesor J. Barrientos García, de la Universidad de Salamanca, analiza los procesos inquisitoriales seguidos contra los hebraístas Luis de León, Gaspar de Grajal y Martín Martínez de Cantalapiedra, hijos de la centenaria casa de estudios. Su hipótesis es que los célebres procesos no sólo frenaron la línea exegética hebraísta y su agudo método filológico, sino que también fueron el símbolo de una derrota de la libertad de enseńanza, del «cierre» de la cultura española. La activa disposición de la universidad para ayudar a los inquisidores habría determinado el silencio y la pasividad con la que el ámbito universitario se sometió a las tentativas impermeabilizantes de Felipe II ( El temor a la Inquisición en la Universidad de Salamanca en tiempos del proceso de Carranza», Anuario de Historia de la Iglesia, n 18, 2009, pp. 181-188). Estos episodios tuvieron lugar entre 1571 y 1578. Paralelamente, el arzobispo Carranza padecía sus diecisiete años (1559-1576) de interminable espera, víctima de una grotesca disputa jurisdiccional (cf. J. I. Tellechea Idígoras, El arzobispo Carranza y su tiempo, Madrid, Guadarrama, 1968, passim). Considerando estos antecedentes, se puede afirmar que para 1584, cuando le llegó el turno a Francisco Sánchez de las Brozas, la Universidad de Salamanca era ya una buena alumna de la pedagogía inquisitorial.

4. Sobre los «partidos» al interior de los claustros salmantinos de latinitas, cf. L. Gil Fernández, Panorama social del humanismo español (1500-1800). Madrid, Alhambra, 1981, p. 39. Sobre los conceptos de intelectualidad «orgánica» e «independiente», cf. L. Gil Fernández, Estudios de humanismo y tradición clásica, Madrid, Universidad Complutense, 1984, p. 39; R. K. Merton, Social Theory and Social Structure, New York, Free Press, 1949 (se cita la edición mexicana: Teoría y estructura sociales, trad. Florentino M. Torner, México, Fondo de Cultura Económica, 1964, p. 217); P. Bourdieu, ofrece una imagen similar al «orgánico» con su «intelectual responsable» 
No sería descabellado suponer que fueran los escrúpulos estéticos del Brocense (así se lo conocía al profesor, oriundo de la extremeña Cáceres) y su erasmista ambición de vivir una "fe verdadera» las fuerzas que lo incitaban a desmantelar los elementos contingentes que envolvían a la liturgia católica postridentina. Pero así como puede pensarse que la dimensión política de sus declaraciones era capaz de comprometer los cimientos de todo un espacio cultural, la religiosidad contrarreformada estaba bien preparada para la defensa considerando que tenía como centinela a un orden confesional que aspiraba a ser impermeable frente a los potentes desafíos heréticos que conmovían a la fe católica, en ese entonces con sus fronteras dogmáticas y doctrinales actualizadas luego de los malhadados consensos del Concilio de Trento (que había sesionado de forma accidentada y discontinua entre 1545 y 1563$)^{5}$.

En España en particular, en la década de 1580 se asistía aún a lo que Dedieu llama el «segundo tiempo de la Inquisición» (c.1525-1620), durante el cual el objetivo principal de las numerosas persecuciones judiciales habría sido vigilar las más cotidianas conductas de los cristianos viejos y sus recurrentes caídas en la bigamia, la simple fornicación, las blasfemias y en proposiciones malsonantes y heréticas ${ }^{6}$. Brozas, en este marco de intolerancia, fue uno más de los tantos que debieron dar explicaciones sobre sus comportamientos sospechosos.

Sin embargo, nuestro protagonista no era uno más. A diferencia de la gran mayoría de los reos que debieron comparecer por motivos de la misma naturaleza, el maestro era un personaje de la llamada «alta cultura». En efecto, entre los casos afectados por el celo inquisitorial en reprimir la oralidad desviada, existió una minoría de hombres instruidos que cayó en la mira de la Inquisición por prosaicas blasfemias y proposiciones heterodoxas ${ }^{7}$. Si bien se ha reconocido que la categoría de «alta cultura» es una ilusión - pues no es difícil percibir a lo largo de la historia fluidos intercambios entre diversos grupos sociales a través de mediadores culturales emanados de cada uno de ellos y que la «cultura popular»

(Homo academicus, Paris, Éditions de Minuit, 1984 -se cita a partir de la edición argentina: Homo academicus, trad. Pablo Tovillas, Buenos Aires, Siglo XXI, 2008, p. 165).

5. Según E. Peters, durante la temprana modernidad «to maintain any belief in opposition to authorative orthodoxy was not merely to set oneself in opposition to theologians and ecclesiastical officials and lawyers [...] but in opposition to a whole culture in all of its manifestations" (Heresy and Authority in Medieval Europe, Philadelphia, University of Pennsylvania Press, 1980, p. 3). Respecto de los factores históricos que dificultaron e interrumpieron el desarrollo normal del Concilio de Trento, cf. A. Prosperi, Il Concilio di Trento: una introduzione storica, Turin, Einaudi, 2001, passim.

6. J-P. Dedieu, «Les quatre temps de l'Inquisition», in B, Bennassar, dir., L'Inquisition espagnole. XV $\mathrm{XV}^{\mathrm{e}}$-XIX ${ }^{\mathrm{e}}$ siècle, Paris, Hachette, 1979 (se cita a partir de la edición española: Inquisición española: poder político y control social, Barcelona, Crítica, 1984, pp. 27-30).

7. M. Boeglin habla de una sensiblilidad especial por parte del Santo Oficio hacia las "perversidades de la lengua» que se profundizó en la segunda mitad del siglo XVI («Les "péchés de la langue" à l'âge de la Contre-Reforme : Inquisition et société à Séville : 1560-1700», en A. Molinié y J-P. Duviols, Inquisition d'Espagne, Paris, Presses de l'Université de Paris-Sorbonne, 2003, p. 146-151). Cf. M. J. Torquemada, Palabra de hereje. La Inquisición de Sevilla ante el delito de proposiciones, Sevilla, Universidad de Sevilla, 1998, pp. 15-22. 
es una etiqueta y lo mismo puede ser afirmado respecto de su espejo creador, la "cultura letrada»- no es menos cierto que la diferencia existía en la conciencia de los contemporáneos, al menos entre estos humanistas tan orgullosos de su especialidad ${ }^{8}$.

Tal vez sea posible, entonces, más allá de la percepción subjetiva del referente, proponer dos argumentos objetivos que permitan considerar a Sánchez de las Brozas -en honor al topos trabajado por Burucúa- un elefante. En primer lugar, no sólo pertenecía a una familia de origen hidalgo, sino que también era un profesor universitario, con todo lo que significaba la vida en aquellas casas de estudio, endogámicas y forzosamente elitistas (acorde con el ascendente prestigio de las letras frente a las armas) ${ }^{9}$. Por otro lado, era un hombre excepcionalmente culto y, según Chomsky, un pensador que con su obra Minerva sive de causis lingue latine habría sabido anticipar el racionalismo cartesiano y la posterior ruptura epistemológica canonizada por la Lógica de Port-Royal ${ }^{10}$. Alfonso Martín Jiménez, por su parte, ha afirmado que las obras

8. Respecto de la naturaleza subjetiva de estas categorías, cf. M. Bajtin, Tvorchestvo Fransua Rable, Moscú, Khudoshestvennia literatura, 1965 (se cita a partir de la edición española: $L a$ cultura popular en la Edad Media y el Renacimiento: el contexto de François Rabelais, trads. Julio Forcat y César Conroy, Madrid, Alianza, 1995, pp. 16-17); J. E. Burucúa, Sabios y marmitones. Una aproximación al problema de la modernidad clásica, Buenos Aires, Lugar, 1993, p.16 y Corderos y elefantes. La sacralidad y la risa en la modernidad clásica. Siglos XV a XVII, Madrid, Miño y Dávila, 2001, p. 26; F. A. Campagne, Homo Catholicus. Homo Superstitiosus. El discurso antisupersticioso en la España de los siglos XV a XVIII, Madrid, Miño y Dávila, 2002, p. 629; R. Chartier, "Cultura popular: retorno a un concepto historiográfico", in Sociedad y escritura en la Edad Moderna, México, Instituto Mora, 1995 (1987), p. 121; C. Ginzburg, Il formagio e i vermi, Turin, Einaudi, 1976 (se cita a partir de la edición española: El queso y los gusanos. El cosmos según un molinero del siglo XVI, trad. Francisco Martín, Barcelona, Península, 2001, p. 27). En relación a la imagen de sí más común entre los humanistas españoles, cf. L. Gil Fernández, Panorama social del humanismo español, p. 268.

9. J. Pérez, "La aristocracia castellana en el siglo XVI», in AA. VV. Nobleza y sociedad en la España moderna, Oviedo, Nobel, 1996, pp. 53-71.

10. Para S. Arduini, Brozas era un «representante típico de la "vanguardia intelectual" de la época» ("La teoría de la elipsis en Francisco Sánchez de las Brozas: ¿̨una anticipación de la gramática generativa?», Anales de Literatura Española, $\mathrm{n}^{\circ}$ 1, 1982, p. 24); M. Bataillon, Érasme et l'Espagne. Recherches sur l'histoire spirituelle du XVI siècle, Paris, 1937 (se cita a partir de la edición española : Erasmo y España. Estudios sobre la historia espiritual del siglo XVI, trad. Antonio Alatorre, Madrid, Fondo de Cultura Económica, 1979, p. 737); L. Gil Fernández, Panorama social del humanismo español, p. 445; M. Foucault, Les mots et les choses, une archéologie des sciences humaines, Paris, Gallimard, 1966 (se cita a partir de la edición argentina: Las palabras y las cosas. Una arqueología de las ciencias humanas, trad. Elsa Cecilia Frost, Buenos Aires, Siglo XXI, 2008, pp. $52-53$ y 8081); N. Chomsky, Language and mind, New York, Harcourt Brace Jovanovich, 1968 (se cita a partir de la edición española: El lenguaje y el entendimiento, trads. Juan Ferraté y Salvador Oliva, Barcelona, Seix Barral, 1971, p. 43). Cf. L. Gil, «Luces y sombras del humanismo español del siglo XVI», in C. Codoñer, S. López Moreda y J. Ureña Bracero, eds., El Brocense y las humanidades en el siglo XVI, Salamanca, Universidad de Salamanca, 2003, p. 18; C. H. Kneepkens, «The Tradition of Universal and Speculative Grammar in the Late Middle Ages», in C. Codoner, S. López Moreda y J. Ureña Bracero, op. cit., p. 32; M. Breva Claramonte, «La aportación del Brocense a la teoría sintáctica del Renacimiento", Actas del Simposio Internacional. IV Centenario de la publicación de la Minerva del Brocense: 1587-1987, Cáceres, 1989, pp. 13-25; C. García, Contribución a la historia 
de Brozas « representan el más claro reflejo en España del proceso de reducción de la retórica al ámbito elocutivo ", contribuyendo así a un acercamiento de la retórica hacia la dialéctica, cuyo fin es, dijo alguna vez uno de los discípulos del gramático, Jiménez Patón, «hacer discursos de razón» ${ }^{11}$. En este sentido, el profesor extremeño habría dado los primeros pasos hacia la conformación de una nueva profesión autónoma: la del lingüista ${ }^{12}$.

La importancia de reconocer la estatura cultural del Brocense y el lugar que ocupaba en la estructura social de la España temprano-moderna es crucial para encarar sus declaraciones, a veces abiertamente peyorativas hacia el pueblo cordero, considerado inculto y supersticioso. Con la habitual autosuficiencia de muchos espíritus libres de la época, entre ellos el mismísimo gran Otro del movimiento reformista español del siglo XVI -Erasmo-, Brozas satirizaba las prácticas populares y, a diferencia del severo discurso que sostenía el Santo Oficio, podría suponerse que las consideraba meras adiaphora ${ }^{13}$. Al mismo tiempo, no con menos convicción ridiculizaba los votos monásticos, parafraseando la máxima erasmista monachatus non est pietas ${ }^{14}$.

de los conceptos gramaticales. La aportación del Brocense, Madrid, CSIC, 1960, passim.

11. A. Martín Jiménez, Retórica y literatura en el siglo XVI: El Brocense, Valladolid, Secretariado de Publicaciones de la Universidad, 1997, p. 45. Cf. L. López Grijera, La retórica en la España del Siglo de Oro. Teoría y práctica, Salamanca, Universidad de Salamanca, 1994, p. 23; B. Jiménez Patón, Elocuencia española en arte, Barcelona, Puvill, 1993 (1604). p. 112. Respecto de la influencia póstuma del pensamiento del Brocense en Jiménez Patón: Cf. A. Madroñal Durán, «El Brocense traducido por Jiménez Patón. (Noticia de una apropiación intelectual.)», Bulletin Hispanique, 111, n 1, junio 2009, pp. 75-107. Cf. A. Ramajo Caño, Las gramáticas de la lengua castellana desde Nebrija a Correas, Salamanca, Universidad de Salamanca, 1987, pp. 54-55.

12. L. Gil Fernández, Panorama social del humanismo español, p. 252.

13. Á $\delta$ ć́ $\varphi \rho \rho \alpha$ o «aquello que es indiferente». El concepto, nacido en el seno del estoicismo clásico, hacía referencia a aquellas acciones y cosas externas que no incidían en la rectitud moral, pero que debían ser juzgadas según su fin. El adiaphoron (el acto o la cosa indiferente) devenía, según Zenón, bueno (axia) o malo (apaxia) según la disposición de la persona. Los primeros cristianos adoptaron el término y lo aplicaron a los hechos externos (comida, bebida, casamiento, riqueza, etc.) regulados por la Vieja Ley, pero moralmente indiferentes bajo la Nueva, en el sentido de que el status ético de estos actos externos estaba determinado por la intención de los actores En el siglo XVI, la idea fue recuperada por los protestantes, especialmente por Melanchthon, quien consideraba que eran adiaphora las creencias, acciones, ceremonias y objetos que no cumplían un rol necesario en la salvación porque no eran ni prescriptos ni prohibidos por las Sagradas Escrituras. La ortodoxia católica y un sector del propio luteranismo rechazó esta interpretación; en cambio, Erasmo no tenía problemas en aceptar que las peregrinaciones y los ayunos, por más que pudieran contribuir a fortalecer la fe, no eran esenciales para la salvación. Incluso, el sabio de Rotterdam también desarrolló la idea de adiaphora doctrinal al plantear que la propia Inmaculada Concepción, el derecho divino de la autoridad de la Iglesia y muchas de las cuestiones alrededor de los sacramentos eran materia opinable (G. Remer, Humanism and the Rethoric of Toleration, Philadelphia, Pennsylvania State University Press, 1996, pp. 50-52). Sobre el uso de este concepto por parte de la intelectualidad católica durante la segunda mitad del siglo XVI, cf. D. Heitsch, Practising Reform in Montaigne's Essais, Leiden, Brill, 2000, pp. 141-163.

14. Sobre el corpus ideológico erasmista, cf. M. Bataillon, Érasme et l'Espagne, pp. 103225; M. De Gandillac, Histoire de la philosophie 2. Encyclopédie de la Pléiade, Paris, Gallimard, 1973 (se cita a partir de la edición española: La filosofía en el Renacimiento, trads. Manuel Pérez Ledesma, Teodoro de Andrés et Joaquín Sanz Guijarro, Madrid, Siglo XXI, 1979, pp. 181- 
Así salía a la luz la herencia humanista, y como se considera que durante el siglo XVI el humanismo conoció tanto su auge como su caída, este artículo se concentra en el canto de cisne de un movimiento intelectual que supo contribuir en buena medida a configurar los puntales básicos de la episteme moderna15. Concretado el cisma protestante, el autónomo método filológico, con su correspondiente vilipendio de la tradición escolástica, el desprecio por las prácticas litúrgicas exageradas y el empeño en una religiosidad íntima, demasiado personal e independiente, características esenciales del humanismo erasmista, así como sus audaces incursiones teológicas, se volvieron cada vez más sospechosas en el universo católico, que les exigía a los humanistas posturas menos tolerantes con los herejes. Los reformados, por su parte, tampoco fueron especialmente receptivos a estos hombres, en general papistas (menos por una creencia en la santidad de los sucesores de Pedro que por el deseo inquebrantable de mantener a la cristiandad unida ${ }^{16}$ ) y ciertamente refractarios a la soteriología radical de las nuevas confesiones ${ }^{17}$. En aquel tiempo de discursos cuya tendencia

190); C. M. N. Eire, War Against the Idols. The Reformation of Worship from Erasmus to Calvin, Cambridge, New York \& Melbourne, Cambridge University Press, 2003 (1986), pp. 28-53; L. Febvre, Érasme, la Contre-Réforme et l'esprit moderne, Paris, École Pratique des Hautes Études, 1957 (se cita a partir de la edición espańola: Erasmo, la Contrarreforma y el espiritu moderno, trad. Carlos Piera, Barcelona, Martínez Roca, 1970, pp. 78-82); M. A. Gillespie, The Theological Origins of Modernity, Chicago, Chicago University Press, 2008, pp. 69-100; J. C. Nieto, El Renacimiento y la otra España, Ginebra, Droz, 1997, p. 408; A. Rabil, jr., Erasmus and the New Testament: the Mind of a Christian Humanist, San Antonio, University Press of America, 1972, passim; L. Suárez Fernández, Humanismo y Reforma Católica, Madrid, Palabra, 1987, pp. 184-191.

15. Se puede hablar de herencia porque hoy existe consenso respecto de que los orígenes del humanismo moderno, en tanto canon epistemológico, pueden ser rastreados hasta los prolegómenos de la baja Edad Media y aún más allá. Cf. I. P. Bejczy, Erasmus and the Middle Ages: The Historical Consciousness of a Christian Humanist, Leiden, Boston \& Köln, Brill, 2001, pp. 191-194; P. Burke, The European Renaissance. Centres and Peripheries, Oxford, Blackwell, 1998, p. 34; G. Capelli, El humanismo italiano. Un capitulo de la cultura europea entre Petrarca y Valla, Madrid, Alianza, 2007, p. 30; S. Gersch y B. Roest, eds., Medieval and Renaissance Humanism. Rhetoric, Representation and Reform, Leiden, Boston \& Köln, Brill, 2003, passim; J. Lafaye, Por amor al griego. La nación europea, señorio humanista (siglos XIV-XVII), México, Fondo de Cultura Económica, 2005, pp. 21-33; A. E. McGrath, The Intellectual Origins of the European Reformation, Oxford, Blackwell, 2004 (1987), pp. 34-43; C. G. Nauert, Humanism and the Culture of Renaissance Europe, Cambridge, Cambridge University Press, 1995, pp. 1-51; L. Suárez Fernández, op. cit., pp. 5-8; R. G. Witt, "In the Footsteps of the Ancients»: The Origins of Humanism from Lovato to Bruni, Leiden, Boston \& Köln, Brill, 2003 (2000), pp. 495-496. Para los antecedentes humanistas desde los primeros siglos cristianos, cf. P. Renucci, L'Aventure de l'humanisme européen au Moyen-Age : IV-XIV siècle, Paris, Les Belles Lettres, 1953, passim.

16. Según L. Suárez Fernández, los humanistas «defendieron el principio social de la unidad, la cual se fundamentaba en la fe. Custodia de esta fe y de los principios morales que de ella dimanaban, era la Iglesia. No se podía sostener una cosa sin la otra. Las desviaciones heréticas [...] contenían también gérmenes de ataque a la estructura política y social de la Cristiandad» (op. cit., p 8). El subrayado es nuestro.

17. Respecto de las diversas posturas soteriológicas durante la Edad Moderna, cf. A. J. Cappelletti, La idea de la libertad en el Renacimiento, Barcelona, Laia, 1986, pp. 31-54; M. A. Gillespie, op. cit., pp. 129-169; A. Rabil, jr., op. cit., pp. 156-182. Sobre la historia de la soteriología cristiana: cf. A. E. McGrath, Iustitia Dei. A History of the Christian Doctrine of Justification, Cambridge, Cambridge University Press, 2005 (1986), passim. 
a la hipérbole se hacía cada vez más evidente que el libre pensamiento era un peligroso privilegio ${ }^{18}$.

Es momento de arriesgar una hipótesis general: si bien, al igual que en la Francia de las guerras civiles, "la crise du XVI siècle est primordialement culturelle, les violences l'assurent», en España la violencia interna fue exitosamente canalizada a través de un sistema judicial-inquisitorial cuya agresividad no era por eso mucho más soslayada -aunque logró ciertamente atenuar las tendencias carnavalescas de los tradicionales pogroms y las recurrentes masacres transpirenaicas ${ }^{19}$. Así, el caso Brozas puede pensarse como la materialización de un conflicto entre dos discursos católicos que, a pesar de los numerosos grises que los comunicaban, representaban dos espacios culturales nítidamente diferenciados que disputaban en torno de la libre interpretación del cristianismo. Por un lado, la arraigada cultura humanista, en este caso con una fuerte impronta erasmista, que retrocedía y se apagaba a medida que los centros del poder político la abandonaban; y, por otro, la reacción contrarreformista inmediatamente anterior a -y precursora de- la cultura barroca, que reconstruía el ecumene cristiano con el apoyo crucial del Estado, cuya participación era cada vez más decisiva en tanto detentador del monopolio de la violencia judicial y proclamado primer defensor de la ortodoxia ${ }^{20}$.

En definitiva, este artículo no es sino un intento de percibir, a través de los registros inquisitoriales, hasta qué punto el caso Brozas es un fiel reflejo (o no) de este combate cultural.

II. Es preciso, ante todo, reconocer el marco histórico que da sentido al problema. Si confiáramos en la hipótesis de Delumeau, podríamos decir que los europeos de la temprana modernidad sufrieron (y alentaron) una novedosa concepción del peligro y, en consecuencia, desarrollaron un riguroso método para combatirlo, basado en la noción de asegurarse. La traducción de esta seguridad sería, naturalmente, la aparición de ambiciosos sistemas represivos, cuyos fines excedían al castigo y se extendían al control y la prevención ${ }^{21}$. Pero el problema no se limita a los contoneos ideológicos y las mutaciones emocionales de la estructura política, sino que también implica sumergirse en el campo del infinito discurso cristiano. Lo que se intenta rastrear aquí son las esquirlas del choque entre el-cristianismo-según-Brozas y el cristianismo oficial de la España filipina.

18. S. Clark, Thinking with Demons. The Idea of Witchcraft in Early Modern Europe, Oxford, Clarendon Press, 1997, p. 62; S. Houdard, Les sciences du diable. Quatre discours sur la sorcellerie (XVte-XVII siècles), Paris, Éditions du Cerf, 1992, p. 30.

19. D. Crouzet, Les guerriers du Dieu. La violence au temps des troubles de religion (vers $1525-$ vers 1610), Paris, Champ Vallon, 2008 (1990), p. 51.

20. Es ilustrativo el juramento de fidelidad hacia el Santo Oficio con el cual Felipe II coronó su adhesión al catolicismo más conservador en el célebre auto de fe del 8 de octubre de 1559: cf. J. C. Nieto, op. cit., pp. 134-135.

21. J. Delumeau, La peur en Occident (XIVE-XVIII siècles). Une cité assiégée, Paris, Fayard, 1978, passim y Rassurer et protéger : le sentiment de sécurité dans l'Occident d'autrefois, Paris, Fayard, 1989, passim. 
Decía Boureau en 1993: «une des originalités fortes du christianisme provient de ce qu'il se fonde sur un récit, beaucoup plus que sur des préceptes [...]. Le christianisme du Moyen Âge se définit par un double mouvement d'amplification et d'abstraction du récit originaire (pour en tirer une doctrine, une liturgie, une institution) $»^{22}$. De Certeau opinaba algo parecido algunos ańos antes: " el cristianismo implica una relación con el acontecimiento que lo instauró: Jesucristo. Presenta una serie de figuras sociales intelectuales e históricas todas colocadas bajo el doble signo de una fidelidad y una diferencia respecto de ese acontecimiento fundador ${ }^{23}$.

Tal vez uno de los relatos más originales de este acontecimiento sempiterno fuera la demonología radical. Y esto remite nuevamente a Boureau, para quien el giro demonológico del siglo XIV denota una discontinuidad definitiva respecto del discurso religioso medieva ${ }^{24}$. Así, está claro que el siglo XVI no es estrictamente una ruptura en la historia de Occidente y de la narración cristiana (la opinión de Boureau permite confirmar la presunción de que ese privilegio lo merece con más justicia el siglo XIV), sino más bien un epítome. El cambio tomó carácter oficial con Juan XXII (1316-1334), aquel pontífice que, a través de la bula Super illius specula de 1326-1327, mudó a la herejía del campo del discurso al de la praxis: el factum hereticale se convertía en el signo visible del apóstata ${ }^{25}$. Por eso, el segundo papa de Avignon puede ser considerado por eso el padre político de la demonología radical, que hacia el siglo XV se había convertido ya en un discurso con una lógica intrínseca, una verdadera ciencia natural del demoni ${ }^{26}$. Se entiende que la demonología radical no era un mero instrumento de un proyecto político -sus bases filosóficas podían presumir orígenes en los grandes doctores de la Iglesia y hasta en los sabios de la Antigüedad-, pero la demostración del carácter ontológico de los espíritus puros no dejaba de inscribirse en un discurso esencialmente neutro, por lo que sería el devenir político, comprendido como un camino que llevaría a la conformación de confesiones distintas dentro de la cristiandad occidental el que daría a la demonología su carácter de creadora de alteridades absolutas, objetivadas mediante pactos con el diablo ${ }^{27}$.

22. A. Boureau, L'Événement sans fin. Récit et christianisme au Moyen Âge, Paris, Les Belles Lettres, 1993, p. 10.

23. M. De Certeau, La faiblesse de croire, Paris, Seuil, 1987 (se cita a partir de la edición argentina: La debilidad de creer, trad. Víctor Goldstein, Buenos Aires, Katz, 2006, p. 215). Subrayado en el original.

24. A. Boureau, Satan hérétique. Naissance de la démonologie dans l'Occident medieval (12801330), Paris, Odile Jacob, 2004, p. 12. Cf. I. Iribarren, «From Black Magic to Heresy: A Doctrinal Leap in the Pontificate of John XXII", Church History, 76:1, 2007, pp. 32-60.

25. Ibid., p. 18. Para relativizar la novedad del factum hereticale, cf. A. Morín, «La herejía medieval entre la sententia errónea y la pura praxis», Actas del III Simposio Internacional sobre Religiosidad, Cultura y Poder, agosto 2010.

26. S. Clark, op. cit., pp. 146-147. Para un estudio textual de la demonología tempranomoderna, cf. A. Maggi, Satan's Rhetoric. A Study of Renaissance Demonology, Chicago, Chicago University Press, 2001, passim.

27. F. Campagne, Strix hispánica. Demonología cristiana y cultura folklórica en la España 
Hasta aquí la tradición; pero el siglo XVI fue también el siglo de la obsesión por el demonio, y la década de 1580 coincidió con la profundización de la segunda etapa (y más sangrienta) de la gran caza de brujas europea ${ }^{28}$. Por eso, el anatema prometía un desenlace cada vez más macabro, si es cierto, como ha asegurado el profesor Eire, que «in the sixteenth century, one man's devotion was another man's idolatry" ${ }^{29}$. Por eso, el hereje, antes cercano y reformable, adquirió entonces rasgos definitivamente diabólicos con el estereotipo del locus que conformaba la apostasía colectiva, el sabbat ${ }^{30}$.

Sin embargo, el contexto europeo no encontró en todas las sociedades que la componían una recepción de la misma naturaleza, pues la información disponible sugiere que la demonología ibérica se mostró moderada, más cercana a la concepción agustiniana de un diablo indefectiblemente derrotado y sujeto al antagónico pero modesto papel que le habría sido asignado por el plan divino, esto es, tentar a los hombres hacia el pecado y la apostasía ${ }^{31}$. Ahora bien, aunque

moderna, Buenos Aires, Prometeo, 2009, p. 292; D. Elliot, Fallen Bodies: Pollution, Sexuality, and Demonology in the Middle Ages, Philadelphia, University of Pennsylvania Press, 1999, pp. 127156; D. Keck, Angels and Angelology in the Middle Ages, New York, Oxford University Press, 1998, pp. 71-114; T. Suarez-Nani, Les anges et la philosophie. Subjectivité et fonction cosmologique des substances séparées à la fin du XIII siècle, Paris, Vrin, 2002, pp. 27-32. Para un estudio sobre los antecedentes grecorromanos de la demonología, cf. G. Luck, Arcana Mundi : Magic and the Occult in the Greek and Roman Worlds. A collection of Ancient Texts, Baltimore, The Johns Hopkins University Press, 1985 (se cita a partir de la edición española: Arcana Mundi. Magia y ciencias ocultas en el mundo griego y romano, trads. Elena Gallego Moya y Miguel E. Pérez Molina, Madrid, Gredos, 1995, pp. 203-270).

28. Cf. W. Behringer, Witches and Witch-Hunts. A Global History, Cambridge (UK), Polity, 2004, pp. 83-195; B. P. Levack, The Witch-Hunt in Early Modern Europe, New York \& London, Longman, 1993, pp. 204-252.

29. C. M. N. Eire, op. cit., p. 5. I. Hunter, J. C. Laursen y C. J. Nederman agregan que «in the wake of Reformation [...] Christians of differing affiliations employed the language of heresy to fing accusations at each other Catholics against Protestants as well as Protestants against one another and against Catholics - so that eventually the epithet "heretical" came to denote nearly any form of apostasy or infidelity» (eds., Heresy in Transition. Transforming Ideas of Heresy in Medieval and Early Modern Europe, Aldershot, Ashgate, 2005, p. 4). El subrayado es nuestro.

30. N. R. C. Cohn, Europe's Inner Demons. The Demonization of Christians in Medieval Christendom, Chicago, The University of Chicago Press, 1973, passim. M. Bailey se ha encargado de aclarar que la asociación entre herejía y brujería no era tan directa como se supone; sin embargo, admite que aquella relación se había forjado en el siglo XIV (Battling Demons. Witchcraft, Heresy and Reform in the Late Middle Ages, Philadelphia, Pennsylvania State University Press, 2003, pp. 34-35). La importancia del humanismo en este derrotero la ha detectado Muchembled al decir que la derrota de los erasmistas, a quienes piensa como partidarios de una religión más interiorizada y menos dramática, dejaría el campo libre para los cuatrocientos ańos venideros cargados con la imagen de un Dios cruel y vengativo (R. Muchembled, Histoire du diable. XII ${ }^{e}-$ $X X^{e}$ siècle, Paris, Seuil, 2000 -se cita a partir de la edición argentina: Historia del Diablo, siglos XII-XX, trad. Federico Villegas, Buenos Aires, Fondo de Cultura Económica, 2002, p. 9).

31. F. Campagne, Strix hispánica, pp. 158-172 y Homo Catholicus, pp. 472 y 475-476; J. Caro Baroja, Las brujas y su mundo, Madrid, Alianza, 1968 (1961), pp. 138-139; R. Muchembled, op. cit., pp. 22 y 37; J. B. Russell, Lucifer. The Devil in the Middle Ages, Ithaca-London, Cornell University Press, 1984, pp. 62-87; J-P. Duviols y A. Molinié-Bertrand, dirs., Enfers et damnations dans le monde hispanique et hispano-américain, Paris, Presses Universitaires de 
menos radical en lo ideológico, los responsables ibéricos de la salud pública no eran menos implacables en la práctica. Tanto frente a las herejías fácticas (iluminismo) como ante las discursivas-intelectuales (derivaciones radicales de la devotio moderna y el humanismo erasmista), se mantuvo firme el espíritu de cruzada $^{32}$. La Inquisición española supo ser el mecanismo represivo más eficaz de la Edad Moderna, por su grado de centralización, por los recursos a su alcance, por su poder político, y merece ser comprendida, entonces, como un eficaz instrumento de disciplinamiento que sirvió a los fines de construcción de un Estado centralizado con un éxito fenomenal ${ }^{33}$.

France, 1996, passim. Según Campagne, al oeste de los Pirineos se percibe una lítote, esto es, una atenuación del discurso demonológico codificado a través del discurso antisupersticioso, que cree en la posibilidad de entablar pactos implícitos con el diablo a partir de prácticas capaces de invocar la acción de seres preternaturales, agentes de ilusiones. En los reinos hispánicos, la opinión hegemónica se apoyaba en la disposición del célebre Canon Episcopi, que dictaminó en el año 906 que los relatos que sobredimensionaban la esfera ontológica de los espíritus puros, atribuyéndoles la capacidad de otorgar poderes sobrenaturales, no eran más que sueños, engaños, ilusiones diabólicas. El discurso teológico español se mostraría ciertamente escéptico frente a la realidad del otro absoluto, de aquel que concretaba un pacto explícito con el diablo. Y no sólo hará pública su incredulidad, sino que declarará herejía la creencia en la realidad de esos sueños extáticos.

32. La devotio moderna fue una tendencia religiosa cuyos orígenes se remontan al siglo XIV, específicamente con la figura de Gherard Groote (1340-1384), predicador holandés que creía que un buen cristiano debía seguir el ejemplo moral de Cristo (antecedente directo del influyente De imitatione Christi de Thomas von Kempen (1380-1471), que tanto impacto generará en Erasmo). Según S. Ozment, The Age of Reform: an Intellectual and Religious History of Late Medieval and Reformation Europe, New Haven, Yale University Press, 1981, p. 79, la devotio moderna era un movimiento "that exalted devout and moral exercises (studium devotum et morale) over purely intellectual pursuits and rejected as useless any endeavor that did not immediately serve inner devotion and ethical practice»; M. A. Gillespie, op. cit., pp. 92-93, por su parte, piensa que, «practically, the devotio moderna was a personal and inward religion of love, faith, and humility that deemphasized works and ceremonies»; J. Delumeau agrega un matiz fundamental a la evolución del movimiento en el siglo XVI, entendiendo su práctica como «el acento sobre la meditación personal, construida y metódica (de manera que escapara a la trampa del iluminismo) y vuelta esencialmente hacia Cristo" (Le catholicisme entre Luther et Voltaire, Paris, Presses Universitaires de France, 1971 -se cita a partir de la edición española: El catolicismo, de Lutero a Voltaire, trad. Miguel Candel, Barcelona, Labor, 1973, pp. 3-4. El subrayado es nuestro). Cf. A. Hyma, The Christian Renaissance: a History of the Devotio Moderna, Hamden, Conn, 1965; R. R. Post, The Modern Devotion: Confrontation with Reformation and Humanism, Leiden, Brill, 1973 (1968). Respecto del «espíritu de cruzada», cf. J. Pérez, «Reformas y heterodoxias. El erasmismo castellano", in A. García Simón, ed., Historia de una cultura. Las Castillas que no fueron, Madrid, Junta de Castilla y León, Consejería de Cultura y Turismo, 1995, p. 113.

33. Así, el paradigma de la confesionalización parece imponerse sin remedio, si es cierta la ilustrativa definición de Contreras, quien considera a aquella como el «incremento de la capacidad de influencia de la Iglesia-Estado en la formación y estructura de los comportamientos». (J. Contreras, «Procesos culturales hegemónicos: de religión y religiosidad. (Reflexiones sobre el hecho religioso. La España del Antiguo Régimen)», in L. A. Ribot García, La monarquía de Felipe II a debate, Madrid, Sociedad estatal para la conmemoración de los centenarios de Carlos V y Felipe II, 2000, p. 336). Subrayado en el original. El historiográfico concepto de confesionalización nació durante la década de 1970 y los autores que se adscriben a este modelo perciben en la temprana modernidad la formación de Estados ciertamente más interesados y, 
En consecuencia, sólo unas cuantas demostraciones de espiritualidad excepcional sobrevivieron al tamiz inquisitorial de lo tolerable en la España del Siglo de Oro. Dentro de la ortodoxia se incluyó a unas contadas representantes del floreciente movimiento místico y hasta una nueva orden, los jesuitas, seguidores de rigurosos ejercicios espirituales. Sin embargo, la otra cara del proceso fue la constante persecución sufrida por las expresiones ibéricas de la spiritualité à la mode, del linaje de las Herejías del Libre Espíritu, llámense quietismo, iluminismo o alumbradismo ${ }^{34}$. Asociados con el protestantismo (el

en efecto, más involucrados en los quehaceres de sus súbditos a través de una mayor diligencia de sus funcionarios públicos y eclesiásticos, verdaderos labradores de un proceso bifronte: disciplinamiento-cristianización. Cf. P. Gorski, The Disciplinary Revolution. Calvinism and the Rise of the State in Early Modern Europe, Chicago, Chicago University Press, 2003; G. Oestreich, Geist und Gestalt des frühmodernen Staates. Ausgewählte Aufsätze, Berlin, 1969; R. Po-Chia Hsia, Social Discipline in the Reformation: Central Europe 1550-1750, London \& New York, Routledge, 1989; W. Reinhard, «Reformation, Counter-Reformation, and the Early Modern State: A Reassessment», The Catholic Historical Review, 75:3, 1989, pp. 383-404; W. Reinhard y H. Schilling, eds., Die katolische Konfessionalisierung, Münster, 1995; José Ignacio Ruiz-Rodríguez e Igor Sosa Mayor, «El concepto de la 'confesionalización' en el marco de la historiografía germana», Studia Historica. Historia Moderna, vol. 29, 2007. Es preciso aclarar que el uso de la palabra confesional no implica necesariamente compartir las premisas y conclusiones de este paradigma. Según explican RuizRodríguez y Sosa Mayor, el concepto de confesionalización tuvo la «fortuna historiográfica» de convertirse en un lugar común en el vocabulario de los historiadores modernistas. Por eso, puede admitirse una relación indisociable entre disciplinamiento, cristianización y consolidación del Estado moderno, y llamarla confesionalización, sin aportarle un sentido histórico determinado, una explicación causal necesaria. Sin embargo, la ausencia de una dirección ineluctable no impide plantear que disciplinamiento y modernidad comparten una afinidad electiva.

Lo cierto es que el tema no puede permanecer ajeno a cualquier acercamiento a la dinámica político-cultural del siglo XVI. Menos aún ante fenómenos relacionados con la Espańa del Siglo de Oro, donde la cuestión política se agrava por la existencia de un aparato reformadorrepresivo excepcionalmente capaz. La Santa Inquisición, institución dedicada en un principio exclusivamente a la herejía judaizante, por estos años se concentraba también en la célebre reforma de costumbres. Elemento fundamental para la unificación de los reinos hispánicos, en tanto -dentro de la lógica de la tesis Anderson, tan polémica como contundente- única institución «espańola» unitaria en la península que sirvió como aparato ideológico para compensar la división y dispersión administrativa reales del Estado, el Santo Oficio también se convirtió en un arma extraordinaria para la creación de súbditos al servicio del Rey (P. Anderson, Lineages of the Absolutist State, New York, NLB, 1974 -se cita a partir de la edición española: El Estado absolutista, trad. Santos Juliá, México, Siglo XXI, 2002, p. 62). Ya hace tiempo, Bataillon vio claramente que la clave fue la inexorable eficacia del sistema inquisitorial, organizado para suscitar delaciones en las que «los más cerrados solían ser delatores de los más doctos y abiertos a la novedad, $y$, a base de palabras imprudentes, promover procesos de los que surgían otras delaciones, base de otros procesos» (M. Bataillon, Erasmo y el erasmismo, trad. Carlos Pujol, Barcelona, Crítica, 2000 (1977), p. 175.).

34. A. W. Keitt, Inventing the Sacred. Imposture, Inquisition, and the Boundaries of the Supernatural in Golden Age Spain, Leiden, Brill, 2005, pp. 78-86; M. Sluhovsky, Believe Not Every Spirit. Possession, Mysticism, and Discernment in Early Modern Catholicism, Chicago and London, Chicago University Press, 2007, pp. 102-112. Sobre el alumbradismo en particular, cf. J. M. García Gutiérrez, La herejía de los alumbrados. Historia y filosofia: De Castilla a Extremadura, Madrid, Mileto Ensayo, 1999; A. Hamilton, Heresy and Mysticism in SixteenthCentury Spain. The Alumbrados, Cambridge, James Clarke \& Co., 1992; A. Huerga, Historia de 
epíteto luterano adquirió una polisemia inusitada, aunque la presencia reformada fue real) y las herejías medievales, sus prácticas fueron sistemáticamente exageradas y anatematizadas, a veces alcanzando su total demonización ${ }^{35}$.

De todos modos, la Inquisición tuvo también un rol más mundano. Desde sus comienzos en 1480 (dos años después de la bula papal Exigit sincere devotionis affectus de 1478, que dio lugar a su creación), el objetivo principal fue la represión de los judaizantes, un enemigo que algunos presumen ficticio, y que, si realmente existió, es posible afirmar que nunca tuvo la magnitud suficiente como para requerir una respuesta represiva tan feroz ${ }^{36}$. Por otra parte, como se mencionó en un principio, el Santo Oficio durante buena parte del siglo XVI (el ya mencionado «segundo tiempo» que se extendió entre 1525 y 1620 aproximadamente) se concentró en corregir los habituales facta heterodoxos de los cristianos viejos y sus habituales proposiciones malsonantes. De todos modos, es posible eludir el debate respecto del peligro real de la herejía judaizante y de las costumbres inconformistas en suelo ibérico mientras la preocupación radique menos en la realidad del delito que en la eficacia de su persecución. Hasta aquí, nada impedirá concluir con Bennassar -y Anderson-

los alumbrados (1570-1630), Madrid, Fundación Universitaria Española, 1978-1994; B. Llorca, La Inquisición española y los alumbrados (1509-1667), Salamanca, Universidad Pontificia de Salamanca, 1985; A. Márquez, Los alumbrados: origenes y filosofía. 1525-1559, Madrid, Taurus, 1972.

35. Respecto de la presencia de la Reforma en España, cf. W. Thomas, Los protestantes y la Inquisición en España en tiempos de la Reforma y Contrarreforma, Lovaina, Leuven University Press, 2001, pp. 345-468. En relación a la lógica de demonización de las sectas heréticas españolas, cf. P. Santonja, «Las doctrinas de los alumbrados españoles y sus posibles fuentes medievales», Dicenda. Cuadernos de Filología Hispánica, n 18, 2000, pp. 353-392.

36. Esta situación diferenció a los reinos hispánicos de sus vecinos, teniendo en cuenta la numerosa población de judíos y musulmanes antes de las expulsiones respectivas de 1492 y 1609. Una hipótesis probable es que ambas minorías fueron un desafío que resultó funcional a la conformación de un Estado espańol unificado, pues, como dice Elliot, en un país carente de unidad política, una fe común servía de sustitutivo y unía a castellanos, aragoneses y catalanes en el propósito único de asegurar el triunfo final de la Santa Iglesia (J. H. Elliot, op. cit. p. 112.). La naturaleza ficticia o real de la herejía judaizante es un debate aún abierto. Entre quienes sostienen la primera de las posiciones: B. Netanyahu, Los orígenes de la Inquisición en la España del siglo XV, Barcelona, Crítica, 2002 (1995), p. XIV, dice que "la mayoría de los conversos eran conscientes asimilacionistas»; H. Kamen, The Spanish Inquisition. A Historical Revision, New Haven \& London, Yale University Press, 1997, pp. 23-24; R. García Cárcel, Orígenes de la Inquisición española. El tribunal de Valencia, 1478-1530, Barcelona, Península, 1976, pp. 44 y 195-199; J. Contreras, "Judíos, judaizantes y conversos en la península ibérica en los tiempos de la expulsión», in A. Alcalá, ed., Judios. Sefarditas. Conversos. La expulsión de 1492 y sus consecuencias, Valladolid, 1995. A la vez, hay quienes sostienen que existe frondosa evidencia para demostrar la existencia real de criptojudaísmo: A. Y. D'Abrera, The Tribunal of Zaragoza and Crypto-judaism, 1484-1515, Brepols, 2008; M. A. García Olmo, Las razones de la Inquisición española, Córdoba, Almuzara ediciones, 2009. El libro de Netanyahu y su opinión respecto al «racismo» de la sociedad española suscitó una fuerte polémica entre los historiadores: para más información, ver «Dossier Netanyahu», Revista de la Inquisición, vol. 8, 1999, pp. 275-346 y R. García Cárcel, «Prólogo» in D. Moreno Martínez, La invención de la Inquisición, Madrid, Marcial Pons, 2004, pp. 11-12. 
que la Inquisición española fue, desde sus oscuros orígenes, el «arma absoluta de la monarquía», poniendo a toda la península bajo su jurisdicción, ignorando las autonomías de los reinos ibéricos ${ }^{37}$.

Así se avanzó paralelamente sobre las libertades concejiles y municipales, retroalimentando, a la vez, la fuerza del tribunal ${ }^{38}$. En esa campaña de conquista jurisdiccional estaba contemplado, naturalmente, el control sobre las universidades, cuya ascendente conflictividad (en particular Salamanca, por ser una institución bicéfala) reclamaba la presencia de una instancia superior de poder: la monarquía ${ }^{39}$. El proceso terminaba de justificarse mediante la fama de las universidades de ser criadoras de herejías y no puede decirse que esta fama fuera completamente injusta, pues el método pedagógico escolástico obligaba a muchos profesores a presentar las doctrinas de los herejes con una profundidad original, lo que contribuía a otorgarles una coherencia inesperada y una difusión publicitaria formidable ${ }^{40}$. El mismo Calvino, por ejemplo, conoció la doctrina de Lutero (si es que podía llamarse doctrina antes de que los católicos la convirtieran en un prolijo corpus ideológico) durante sus efímeros estudios de teología en Paris ${ }^{41}$. En este contexto se entiende la aciaga pragmática de noviembre de 1559 a través de la cual se prohibía a los estudiantes españoles estudiar en el extranjero, que a la larga se demostraría responsable de muchas de las deficiencias estructurales de la cultura española en las postrimerías de la Edad Moderna.

En Salamanca en particular, ya se ha hecho referencia al grado de intromisión logrado por la Inquisición en la vida interna de la universidad; resta ahora reconocer las formas de la resistencia, no menos tenaces.

III. El caso del gramático extremeño ofrece una perspectiva singular: no era un teólogo y no era en ese campo donde libraba sus batallas discursivas; tampoco se consideraba un reformador, ni aspiraba a serlo. No es menos cierto que, como tantos otros, el profesor era un fiel erasmista y en cuanto -según Bataillon- el

37. B. Bennassar, Inquisición española, p. 327.

38. J. Contreras, Sotos contra Riquelmes. Regidores, inquisidores y criptojudios, Madrid, Muchnik, 1992, passim; J-P. Dedieu, «El personal inquisitorial en el reinado de Felipe II», in L. A. Ribot García, op. cit., p. 382.

39. M. P. Alonso Romero, «Sobre la jurisdicción y el gobierno de la universidad de Salamanca a fines del siglo XVI», Studia Historica. Historia Moderna, vol. XI, 1993, p. 31; F. J. Alejo Montes, La universidad de Salamanca bajo Felipe II: 1575-1598, Burgos, Junta de Castilla y León, 1998, passim; R. Kagan, Universidad y sociedad en la España moderna, Madrid, Tecnos, 1981, passim; P. Marzal Rodríguez y M. Pesset, " Humanismo tardío y el gobierno de la Universidad de Salamanca a fines del siglo XVI », Studia Historica. Historia Moderna, vol. XIV, 1996, pp. 63-84.

40. Respecto del método escolástico, cf. A. Boureau, «Le sabbat et la question scolastique de la personne», in N. Jacques-Chaquin y M. Préaud, dirs., Le sabbat des sorciers en Europe, Paris, Jérôme Millon, pp. 33-46; A. Martínez Lorca, «El método escolástico: desarrollo histórico y evolución doctrinal», Pensamiento: Revista de investigación e información filosófica, vol. 59, $\mathrm{n}^{\circ} 225,2003$, pp. 431-452.

41. Cf. J. Delumeau, Naissance et affirmation de la Réforme, Paris, PUF, 1965 (se cita a partir de la edición española: La Reforma, trad. José Termes, Barcelona, Labor, 1973, p. 56). 
erasmismo era un movimiento fideísta, que oponía a la autoridad de la razón teológica, no la razón simplemente, sino la sumisión a Cristo cuya gracia daba una libertad interior, Brozas reivindicaba su libre conciencia, íntimamente relacionada con la sinceridad de $s u \mathrm{fe}^{42}$. Su inconformismo público puede ser pensado como producto de una íntima y personal necesidad.

Se impone una pregunta inevitable: ¿por qué el Brocense, hombre instruido y alerta -que, es preciso decirlo, conocía de primera mano el procedimiento inquisitorial por su propia participación en algunas actividades de censuracorrería deliberadamente el riesgo de verse cercado por el Santo Oficio ${ }^{43}$ ? Evidentemente, si la palabra debía ser fiel a la creencia, pero la amenaza inquisitorial obligaba al encubrimiento, el humor podía convertirse en un arma polémica indispensable ${ }^{44}$. Siguiendo a Burucúa, es posible afirmar que se nutría de uno de los pilares de la tradición renacentista: la risa, que, mucho más que un recurso retórico, era «una componente íntima del modo de la argumentación» ${ }^{45}$.

Algunos ejemplos. Durante los primeros interrogatorios, en enero de 1584, Pero Sánchez, un clérigo portugués que vivía en ese momento en la casa del Brocense, declaró haber escuchado al maestro decir " que los teólogos no saben nada: que si él fuera teólogo, que a ellos debían quemar juntos o a él solo, encareciendo lo que él sabía ${ }^{46}$. Por esos mismos días, Francisco López, estudiante de teología, asistente a las clases de retórica de Brozas, confesó haberlo oído decir "que aunque muchos frailes dominicos pensaban que la fe de Cristo estaba fundada en Santo Tomás, que en este caso “¡mierda para Santo Tomás!”, que no estaba fundada sino en los apóstoles de Cristo, y que aunque no hubiera Santo Tomás, que no había de faltar la fe de Cristo ${ }^{47}$. En la primera audiencia en que compareció el maestro, el 24 de septiembre, la fuente afirma que dijo: «si me prueban que mi fe está fundada en Tomás, yo cagaré en ella y buscaré otra $»^{48}$. Por ese entonces, además, se comentaba que el acusado solía repetir un satírico refrán: "quien dice mal de Erasmo o es fraile o es asno» ${ }^{49}$.

No obstante, el humor era una pista demasiado transparente para los curtidos guardianes de la fe. El caso Brozas evidencia no sólo una dinámica persecutoria que atacaba el desafío del libre pensamiento, sino también a la gran enemiga de la fe: la soberbia; no es casual que sucesivos testimonios acusaran al gramático

42. M. Bataillon, Érasme et l'Espagne, p. 737. Sobre el método exegético de Erasmo, cf. A. Rabil, op. cit., pp. 141-156.

43. V. Bécares Botas, «El Brocense: de censor a censurado, con otras menudencias», Anuario de Estudios Filológicos, 13, 1990.

44. Sobre las estrategias retóricas de Erasmo, cf. C. M. N. Eire, op. cit., p. 47.

45. J. E. Burucúa, Corderos y elefantes, p. 121. Haciendo uso de la elegía del humor hecha por U. Eco, podría afirmarse que se está en presencia de «un juego filosófico supremo» («Los marcos de la "libertad" cómica», in AA.VV., ;Carnaval!, México, FCE, 1989, p. 20).

46. B. N. Ms. 12745 , fol. 10 r.

47. Ibid., fol. $17 \mathrm{v}$.

48. Ibid., fol. $37 \mathrm{v}$.

49. Ibid., fols. 62 r. y 84 v. 
de arrogante, insolente, atrevido y mordaz ${ }^{50}$. El infame propósito de reforma de costumbres de la modernidad no sólo se empeñaba en enderezar las verdades erradas, sino que también buscaba descabezar las subversiones mínimas, capaces de poner en duda los cimientos de la fe desde sus elementos más discretos. No es momento ni lugar para sumergirse en el frondoso debate sobre, como lo llama Eco, « los marcos de la "libertad” cómica", pero el caso Brozas parece confirmar la tesis del filósofo italiano, en tanto el humor, amargo « carnaval frío ", parece el único sistema de signos metasemiótico capaz de poner en duda otros códigos culturales -en este caso, la ornamentada religiosidad contrarreformista ${ }^{51}$. Lo cierto es que los inquisidores tenían bien claro el peligro del escándalo, voz que en aquellos tiempos refería a la capacidad de reproducir opiniones falsas entre los cristianos de a pie, tan susceptibles a lo malsonante ${ }^{52}$.

Esta cuestión se inserta en el más amplio problema de la heterodoxia. Agustín en su De heresibus ad Quodvultdeum, 7, advirtió desde un principio que no todo error era herejía, por lo que la clave residía en el discernimiento ${ }^{53}$. Por eso, en el comienzo del segundo milenio, ante la explosión de las herejías populares, los esfuerzos por definir los límites de la ortodoxia se multiplicaron ${ }^{54}$. Considerando la paradigmática definición medieval enunciada por Grosseteste en 1230 (" haresis est sententia humana sensu electa, sacra scriptura contraria, palam edocta, pertinaciter defensa »), puede pensarse que lo que Nicolás Eimeric enunció en 1376 le adjuntó una sutil y decisiva diferencia: herejía era cualquier oposición a la verdad declarada por la Iglesia o los libros canónicos ${ }^{55}$.

50. Cf. A. Holgado, «El Brocense o la arrogancia del saber», Actas del Simposio Internacional. IV Centenario de la publicación de la Minerva del Brocense: 1587-1987, pp. 61-79.

51. U. Eco, op. cit., p. 19.

52. A. W. Keitt, op. cit., p. 1; A. Szabari, Less Rightly Said. Scandals and Readers in SixteenthCentury France, Stanford, Stanford University Press, 2010, pp. 9-14. Esta posición puede encontrar fundamentos teológicos en el Mateo 18:6 ("qui autem scandalisaverit unum de pusillis istis qui in me credunt expedit ei ut suspendatur mola asinaria in collo eius et demergatur in profundum maris») y en la Summa Theologia, II-II, quastio 43, art. 1 ("Contingit enim quod quandoque aliquis obex ponitur alicui in via corporali, cui impingens disponitur ad ruinam, et talis obex dicitur scandalum. Et similiter in processu via spiritualis contingit aliquem disponi ad ruinam spiritualem per dictum vel factum alterius, inquantum scilicet aliquis sua admonitione vel inductione aut exemplo alterum trahit ad peccandum. Et hoc proprie dicitur scandalum $")$.

53. "Non enim omnis error haresis est, quamvis omnis haresis qua in vitio ponitur nisi errore aliquo haresis esse non possit. Quid ergo faciat haereticum regulari quadam definitione comprehendi, sicut ego existimo, aut omnino non potest aut difficillime potest».

54. Cf. G. R. Evans, A Brief History of Heresy, Oxford, Blackwell, 2003, pp. 90-133; M. Lambert, Medieval Heresy: Popular Movements from the Gregorian Reform to the Reformation, Oxford, Blackwell, 2002 (1977), p. 5; R. I. Moore, The Formation of a Persecuting Society, Oxford, Blackwell, 1987, p. 4; E. Peters, op. cit., pp. 3-4.

55. Citado en M. D. Chenu, "Orthodoxie et hérésie. Le point de vue du théologien ", in J. Le Goff, comp., Hérésies et sociétés dans l'Europe pré-industrielle, Paris, Mouton, 1968 (se cita a partir de la edición española: Herejías y sociedades en la Europa preindustrial, siglos XIXVIII, trads. Flora Guzmán, José Manuel López, Dolores Sacristán et Héctor Tizón, Madrid, Siglo XXI, 1987, p. 2). El contexto de esta definición ha sido reconstruido con precisión por R. W. Southern, Robert Grosseteste. The Growth of an English Mind in Medieval Europe, Oxford, Oxford University Press, 1986, p. 292. 
De esta manera, cubría el involuntario vacío acerca del papel de la Iglesia en la definición de lo que es contrario a los libros sagrados. El proceso de centralización del poder de discernimiento avanzaría mediante el famoso comentario de Francisco Peña, quien actualizó el Directorium Inquisitorum de Eimeric, en pleno anticlimax post-Lepanto, afirmando que «hay herejía y hay secta cuando hay comprensión o interpretación del Evangelio no conforme a la comprensión y a la interpretación tradicionalmente defendida por la Iglesia Católica» ${ }^{56}$. Esta definición terminó con cualquier ambigüedad: «a la Iglesia atañe explicar los contenidos implícitos, pues ella es el fundamento mismo de la verdad, ${ }^{57}$. En un tiempo huérfano de criterios universales de verdad, Trento, a su vez, confirmaría los caminos de la ortodoxia y sus necesarios anatemas.

Es sugestiva, en este sentido, la propuesta de Dedieu, para quien es en el carácter ad hoc de la ortodoxia, que necesita una herejía de naturaleza circunstancial, donde radica su mayor fuerza ${ }^{58}$. Así, parece confirmar la vieja sugerencia paulina: oportet esse hareses (Corintios I 11:19) y podría entrar en juego la apreciación de Tomás en la Summa Theologia (II-II, quastio 11, art. 1), donde definía al hereje como quien perpetraba una corrupción de los dogmas cristianos, ejercitando un vicio producto de la soberbia ${ }^{59}$. Probablemente aquí se encontrara el punto débil de la defensa del Brocense, en tanto sus errores

56. Respecto del «anticlímax» de los años posteriores a la Batalla de Lepanto de 1571, cf. J. H. Elliot, Imperial Spain. 1469-1716, Londres, 1963 (se cita a partir de la edición española: La España imperial. 1469-1716, trad. Joan-Lluís Marfany, Barcelona, Vicens-Vives, 1969, p. 260). En relación al manual: N. Eimeric y F. Peña, El manual de los inquisidores, trad. Luis Sala Molins, Barcelona, Muchnik, 1983, p. 58. En opinión de M. Boeglin, con el Manual «se creaba un instrumento para combatir la herejía mediante la palanca del Santo Oficio, el cual recibía al mismo tiempo la consagración doctrinal y el reconocimiento de su papel en la sociedad» (Inquisición y Contrarreforma. El tribunal del Santo Oficio de Sevilla. 1560-1700, Sevilla, Espuela de Plata, 2006, p. 252).

57. N. Eimeric y F. Peña, op. cit., p. 60.

58. Cf. J-P. Dedieu, L'administration de la foi. L'Inquisition de Tolède (XVI'-XVIII siècle), Madrid, Casa de Velázquez, 1989, p. 243. Cf. J.B. Henderson, The Construction of Orthodoxy and Heresy: Neo-Confucian, Islamic, Jewish and Early Christian Patterns, New York, NYU, 1998, p. 2; I. Hunter, J. C. Laursen y C. J. Nederman han notado, a su vez, que el concepto de herejía se radicalizó durante el Renacimiento, tendiendo a ampliar su alcance hacia la mera diferencia de opinión (op. cit., p. 4).

59. «...vitia habent speciem ex fine proximo, sed ex fine remoto habent genus et causam. Sicut cum aliquis moechatur ut furetur, est ibi quidem species moechice ex proprio fine et obiecto, sed ex fine ultimo ostenditur quod moechia ex furto oritur, et sub eo continentur sicut effectus sub causa vel sicut species sub genere, ut patet ex his que supra de actibus dicta sunt in communi. Unde et similiter in proposito finis proximus haresis est adharere falsa sententia propria, et ex hoc speciem habet. Sed ex fine remoto ostenditur causa eius, scilicet quod oritur ex superbia vel cupiditate. [...] sicut heresis dicitur ab eligendo, ita secta a sectando, sicut Isidorus dicit, in libro Etymol., et ideo heresis et secta idem sunt. Et utrumque pertinet ad opera carnis, non quidem quantum ad ipsum actum infidelitatis respectu proximi obiecti, sed ratione causa, que est vel appetitus finis indebiti, secundum quod oritur ex superbia vel cupiditate, ut dictum est; vel etiam aliqua phantastica illusio, qua est errandi principium, ut etiam philosophus dicit, in IV Metaphys. Phantasia autem quodammodo ad carnem pertinet, inquantum actus eius est cum organo corporali.» 
y su jactancia fueron, en las últimas instancias del proceso, confundidos peligrosamente con la desviación límite.

Es necesario, entonces, comprender qué lugar le corresponde al caso Brozas en esta dinámica pragmática considerando las proposiciones que fueron consideradas heréticas en la primera sentencia. En primer lugar, se consideró que decir "que no había de haber imágenes y que es bobería hacer y pintar, y que si no fuera porque los herejes tienen opinión que las había de haber, y si no fuese por condescender con su voluntad, ya las habrían quitado, y que el desnudarlas era señal de que las querían quitar» iba contra la sesión XXV del Concilio de Trento y contra la costumbre ${ }^{60}$. Aquí, el personal inquisitorial salía en defensa de uno de los elementos fundamentales de la tradición y de la pedagogía contrarreformista, que, reticente a la alfabetización del vulgo, intentaba instruirlo, presa de su propio impulso espectacular, que preanunciaba la disposición referencial barroca, basada en el teatro, la fiesta y la imagen, casi como expresiones materiales de la hipérbole imperante en la cultura de la época. Los argumentos esgrimidos se escudaban, tal como sugería el espíritu tridentino, en la tradición conciliar y en la autoridad de los padres de la Iglesia ${ }^{61}$.

Lo mismo puede decirse de otra proposición que fue considerada herética por los calificadores: aquella declaración acerca de que «eran bobos los que se hincaban de rodillas para adorar las imágenes por las calles, y que sólo había que adorar a nuestro Señor y a su cruz, donde él murió» ${ }^{62}$. No es distinto cuando se condenó eso de que «sólo se ha de adorar a las santas y santos del cielo y no a los que estaban acá, porque son un poco de palo y yeso» ${ }^{63}$. A la Inquisición le interesaba dejar en claro que, dentro de la gran batalla de la modernidad acerca de quién detentaba el monopolio del discernimiento, sólo a la Iglesia Católica correspondía dictaminar qué era ortodoxo y qué no ${ }^{64}$.

60. B. N. Ms. 12745 , fol. 21 v.

61. San Gregorio Magno decía: «...quod legentibus scriptura, hoc ex idiotis prastat pictura; quia in ipsa ignorantes vident quid sequi debeant, in ipsa legunt qui literas nesciunt», citado por J. E. Burucúa, Corderos y elefantes, p. 56. B. Bennassar, "Contrarreforma y repliegue cultural», in A. García Simón, ed., op. cit., pp. 142-143; F. De La Flor, «Del Barroco a la Posmodernidad: arqueología de la sociedad del espectáculo", in AA.VV, Fiesta, juego y ocio en la historia, Salamanca, Universidad de Salamanca, 2003, pp. 125-145; J. A. Maravall, La cultura del barroco: análisis de una estructura histórica, Madrid, Ariel, 1975, p. 92. Sobre el valor de la imagen en el discurso de poder en las sociedades católicas, cf. G. Balandier, Le pouvoir en scène, Paris, Fayard, 1980; Y-M. Bercé, Le roi caché. Sauveurs et imposteurs. Mythes politiques populaires dans l'Europe moderne, Paris, Fayard, 1990; F. Bouza, Imagen y propaganda. Capitulos de historia cultural del reinado de Felipe II, Madrid, Akal, 1988; J. Goody, La peur des représentations, Paris, La Découverte, 2003; P. Legendre, Dieu au miroir. Essai sur l'institution des images, Paris, Fayard, 1994; L. Marin, Le Portrait du roi, Paris, Minuit, 1981; P. Martínez-Burgos García, Ídolos e imágenes. La controversia del arte religioso en el siglo XVI español, Valladolid, Universidad de Valladolid-Caja Salamanca, 1990; J. M. Morales Folguera, Cultura simbólica. Arte efimero en Nueva España, Granada, Junta de Andalucía, 1991.

62. B. N. Ms. 12745 , fol. 21 r.

63. Ibid., fol. $21 \mathrm{v}$.

64. Respecto del discernimiento de espíritus durante la Edad Media y Moderna, cf. W. L. Anderson, Free Spirits, Presumptuous Women, and False Prophets: The Discernment of 
Pero el Brocense también fue llamado por otro tipo de declaraciones que son lítotes de herejía: las consideradas temerarias, malsonantes, errores. Entre ellas se encontraban: «que Cristo no fue circuncidado del Santo Simeón sino que su madre lo hizo en su casa" " ${ }^{65}$; "que los Reyes Magos tal vez no eran reyes, porque el Evangelio sólo dice quod magi ab Oriente verunt" ${ }^{66}$; "que los Reyes Magos no habían venido a adorar a nuestro Señor luego que nació sino después de dos años» ${ }^{67}$; «que los teólogos no saben nada» (ésta fue considerada también "proposición injuriosa»); "que Santa Lucía no se había sacado los ojos y que era abogada de los ojos porque Lucía provenía del verbo lucere $^{68}$. Además, al increíble insulto a Santo Tomás mencionado al inicio se lo declaró blasfemia ${ }^{69}$.

Cuando Brozas fue llamado a responder, admitió que «en Salamanca lo llaman "hombre arrojado y atrevido y que da escándalo", pero que él no da sino que ellos le toman, pues él obedece a la Santa Madre Iglesia, por lo que está presto de retractarse y reducirse a la Iglesia y que todo lo ha dicho por curiosidad y no por enseñar mala doctrina» ${ }^{70}$. Aclaró también que «siempre ha hecho la salva de no entrometerse en artículos de fe ni en lo ordenado por la Iglesia y los Concilios, aunque sí discute aquello que toca a la filosofía o historia sagradas o profanas, en que los teólogos son bien ignorantes» ${ }^{71}$. Además, no se rindió cuando, a pesar de no reconocer haber insultado al Doctor Angélico, admitió que "en cosas de filosofía hartas cosas pueden mostrarse contra Tomás» ${ }^{72}$.

Los calificadores, finalmente, recomendaron: «merece ser reprehendido y castigado porque fuera de su facultad se arroja sin discreción y si no le van a la mano, verná (sic) a afirmar herejías y errores manifiestos» ${ }^{73}$. Los jueces, sin embargo, se mostraron clementes. Hacia fines de septiembre, citaron al maestro, lo reprehendieron y le advirtieron "que en adelante no caiga en semejantes cosas, si no que será castigado con mucho rigor [y] que tenga y guarde secreto de todo lo que pasón ${ }^{74}$.

El tribunal seguía las directivas de la Suprema y su mensaje inconmovible; se sabe: en estos tiempos, el escándalo era la presa más codiciada por la justicia inquisitorial y secular. Si un hombre no amaba las normas, al menos debía

Spirits y in the Late Middle Ages, Chicago, Chicago University Press, 2002, passim; N. Cacciola, Discerning Spirits. Divine and Demonic Possession in the Middle Ages, Ithaca \& London, Cornell University Press, 2003, passim; Sluhovsky, op. cit., passim.

65. B. N. Ms. 12745, fol. 21 r. Curiosamente, esta misma idea sería sostenida pocos años después por el maestro y suegro de Velázquez, Francisco Pacheco del Río (1564-1654), sin ser víctima de persecución alguna (cf. F. Pacheco, Arte de la pintura, Madrid, Cátedra, 1990, pág. 589).

66. Ibid., fol. 23 r. y 24 r.

67. Ibid., fol. 23 r.

68. Ibid., fol. $24 \mathrm{v}$.

69. Ibid., fol. $24 \mathrm{v}$.

70. Ibid., fol. $34 \mathrm{r}$.

71. Ibid., fol. $37 \mathrm{r}$.

72. Ibid., fol. $37 \mathrm{v}$.

73. Ibid., fol. 43 r. El subrayado es nuestro.

74. Ibid., fol. 43 v. 
convivir en silencio. Además, el secreto era un elemento fundamental en la maquinaria inquisitorial, tal vez una de las más potentes razones del miedo, junto con la lesión del honor de la familia, las consecuencias económicas que conllevaba un proceso y el carácter ejemplar de los castigos ${ }^{75}$.

Pero el maestro Sánchez era demasiado obediente a sus necesidades espirituales, por lo que en los nueve ańos que transcurrieron entre la sentencia de 1584 y el nuevo proceso que se le inició en 1593 (sin su conocimiento), contrarrestó su obediente condición de «Comisario del Índice Expurgatorio encomendado por Sixto $\mathrm{V}$ a la Universidad ${ }^{76}$ con la publicación, no sólo de la ya mencionada Minerva en $1587^{77}$, sino también de una obra claramente heterodoxa: De nonnullis Porphyrii aliorumque in dialectica erroribus (1588, con reedición en 1597). La exposición no pudo ser más oportuna: entre 1587 y 1593, la maquinaria política del Rey Prudente estaba demasiado ocupada en capear lo que Kamen llama el "tiempo del trueno»" ${ }^{78}$.

Ignoradas las sutilezas de la Minerva en el registro de los procesos, las sospechas se concentraron en De nonnullis Porphyrii. Según el calificador fray Francisco Arce, en esa obra Brozas habría propuesto que las artes estaban corrompidas, lo cual significaría

una proposición desatinada, temeraria y perniciosa, porque cosa es muy clara que ningún arte, oficio ni ciencia hay que moralmente hablando se pueda saber sin que el discipulo aprenda, oiga y al principio crea a su maestro. En el Concilio de Constanza sesión VIII se condena por error XXIX lo que dijo Wycliff, que las universidades, colegios, estudios, grados y magisterios son cosas vanas y gentílicas; $y$ a este error favorece mucho esta proposición, porque si los discípulos no han de creer y el creer es la primera causa de que las artes estén corrompidas, ¿de qué sirven las universidades, lecciones, colegios, estudios, maestros y preceptores? Y si los discípulos no dan crédito a sus maestros, sino por su ingenio sólo quieren saber las artes y las ciencias, darán en mil disparates y errores, y perderán

75. B. Bennassar, L'Inquisition espagnole, pp. 111-125: aquí, el autor sostiene la interpretación clásica de Lea, para quien " the most marked distinction between the procedure of the Inquisition and that of the other jurisdictions was the inviolable secrecy in which all its operations were shrouded. There were, indeed, other evil peculiarities, but this it was which inflicted the greatest wrong on its victims and exposed the inquisitor to the strongest temptation to abuse his power " $(\mathrm{H}$. C. Lea, History of the Inquisition of Spain, London, The Macmillan Company, 1906, vol. II, p. 470). W. Thomas no comparte esta visión, y prefiere otorgar una mayor responsabilidad a los españoles en la vigilancia de sus propios vecinos, proponiendo un " modelo de consenso y conformismo sociorreligioso " (op. cit., p. 30).

76. V. Bécares Botas también señala la participación de Brozas en la censura de una obra de Juan Pérez de Moya en 1557 (op. cit., p. 40).

77. Según J. M. Liaño Pacheco, la primera edición de la Minerva data de 1563 (Sanctius, El Brocense, Madrid, 1971, pp. 11-18). Según Breva Claramonte, por su parte, en aquella obra, Brozas desarrolló en plenitud su teoría de la sintaxis lógica, convirtiéndose en uno de los primeros gramáticos que «menciona de modo consciente que las estructuras lógicas u ordinarias (cause) no han de estar atestiguadas en los autores para ser válidas [pues] se trata de constructos teóricos que explican la regularidad o analogía de la lengua lógica primordial» («La aportación del Brocense a la teoría sintáctica del Renacimiento", p. 23).

78. H. Kamen, Philip of Spain, New Haven, Londres, Yale University Press, 1997 (se cita a partir de la edición española: Felipe de España, trad. Patricia Escandón, Madrid, Siglo XXI, 1998, pp. 284-318). 
mucho tiempo, lo cual ahorran aprovechándose de los trabajos y estudios de sus maestros y creyéndoles, y lo contrario es desatino pernicioso en las costumbres ${ }^{79}$.

El argumento era significativamente alérgico al libre pensamiento. En el mismo sentido, Arce acusó al Brocense de jactarse «de que en tres años de estudios de filosofía nunca creyó nada de cuantas cosas sus maestros le enseñaron, y esto dice que le vino de Dios. Como las artes y la filosofía algunas veces se tocan cosas de nuestra fe, la proposición es arrogante e insolente, y arguye ánimo libre, indócil y dispuesto para cualquier error, y lo peor es que esto lo atribuye a Dios» ${ }^{80}$. También dijo que se burlaba de las reglas de la dialéctica, enunciando «doctrina peligrosa y perniciosa de Erasmo y Lutero y de los herejes, que porque con la dialéctica les hacen guerra, querrían desarmar a los católicos de ella, infamándola» ${ }^{81}$. Se lo acusó también de escribir que no había que creerle a nadie que no probara sus afirmaciones con argumentos y razones firmes. Para el calificador era claro que

si se cree esta proposición, es grande herejía de los gentiles y paganos maniqueos, que ninguna cosa quieren creer sino por razón natural, y esto es decir que no ha de haber fe sobrenatural. Mas porque este autor justa subjectam materiam habla de cosas naturales, se puede excusar de herejía esta proposición, pero no de atrevida e insolente, que también en las cosas naturales vale mucho la autoridad de los doctos y a cada uno en su arte se le debe crédito, aunque lo pruebe por razones ${ }^{82}$.

Arce concluyó con una declaración insuperable:

el autor demuestra ser muy insolente, atrevido y mordaz, como son todos los gramáticos y erasmistas; y aunque la doctrina que aquí enseńa no sea directa e inmediatamente contra la fe por tratar de lógica y cosas naturales, pero puede hacer mucho estrago en la Iglesia, porque si lo que enseña es verdad, bien se puede quemar toda la teología y filosofía que hay impresa del maestro de las sentencias, de Alberto Magno, Alejandro de Alés, Tomás, Buenaventura, Scoto, Durando, Cayetano, etc. y todo lo que se enseña en las universidades de Salamanca, Valladolid, Alcalá, Paris, Bolonia, Lovaina, Tolosa, etc. Pues este autor destruye los fundamentos de la lógica, de los cuales se sirve la teología escolástica y aun la antigua de los santos, que toda es una reducida a arte, en la cual muchas veces se toma una premisa de fe y otra de ciencia natural, y se infiere una conclusión teológica, y si se toma una proposición natural de este autor con otra de fe, se inferirá una conclusión herética. Pero este autor no lo consideró así, por lo que no lo tomo como hereje, mas su doctrina es nueva, peligrosa y perniciosa, y causa de muchos errores en la fe a los que fiados en ella tratasen cosas de teología, y muy contraria a los principios naturales que los santos siguen ${ }^{83}$.

Como si no fuera suficiente, flamantes acusaciones ubicaron a Brozas en la peligrosa categoría de pertinaz. Se repitieron las insinuaciones acerca de su escepticismo respecto de la alcurnia de los Reyes Magos y de la devoción a las imágenes. Se acercaron, además, nuevas proposiciones: "que María no es de

79. B. N. Ms. 12745, fol. 53 r. El subrayado es nuestro.

80. Ibid., fol. 53 v. El subrayado es nuestro.

81. Ibid., fol. $53 \mathrm{v}$.

82. Ibid., fol. 53 v. El subrayado es nuestro.

83. Ibid., fol. 55 r. El subrayado es nuestro. 
la tribu de Judá»" ${ }^{84}$; "que María estaba muy sosegada cuando parió a Cristo y que no fue en el pesebre» ${ }^{85}$; "que Cristo no nació en diciembre, sino en septiembre» ${ }^{86}$; "que en el nacimiento de Cristo no había habido pastores, que "el diablo llevo allí los pastores"»" "qque entiende mejor que San Jerónimo cierto vocablo latino o griego» ${ }^{88}$; "que dentro de doce ańos y medio se había de perder España, y que lo sabía por astrología por cierto eclipse de sol que entonces habría»" ${ }^{89}$; que Erasmo era muy docto en letras de humanidad y que había hecho mucho servicio a la Iglesia en lo que escribió sobre la Escritura» ${ }^{90}$ (se recordará que la obra del sabio de Rotterdam había sido incluida en el Índice expurgatorio de 1559).

Brozas recién fue llamado a Valladolid en noviembre de 1600, luego de que su casa fuera requisada y sus papeles confiscados. En la primera audiencia, el maestro dijo que sabía que algunas personas le miraban las manos para ver lo que decía (ésta era una expresión en boga en estos tiempos) y que habían interpretado maliciosamente sus palabras, tergiversando el sentido por él impreso ${ }^{91}$. Una vez más, proclamó que nunca quiso apartarse de la fe, y que no había escrito ni dicho nada que fuera en contra de ella. Aseguró comprender que todo lo que escribía estaba destinado a pasar por la censura del Santo Oficio, donde debía enmendarse aquello que lo mereciera. Insistió en que fue siempre un fiel católico, y que, en el caso de haber dicho o hecho algo que pareciera ir contra la fe católica, estaba dispuesto a confesarse y a reducirse a la unión de la Iglesia católica romana. La tercera audiencia terminó con un sentido ciertamente trágico, porque el maestro intentó dejar en claro que

en cuanto a las cosas que no son de fe no quiere cautivar su entendimiento sino interpretarlas conforme a lo que ha estudiado; y lo mismo hace con los autores antiguos, porque a Platón y a Aristóteles, no quiere creerles si no es a través de la razón. Tiene por malo creer a los maestros, porque para que uno sepa es necesario no creerlos sino ver lo que dicen, como Euclides, y otros maestros de matemáticas que no piden que los crean sino que con la razón o evidencia entiendan lo que dicen ${ }^{92}$.

El Brocense murió poco después de estas palabras. Su última aparición en la fuente es bajo el ropaje de, según la acusación del fiscal, un «hereje protervo, contumaz y obstinado»" ${ }^{33}$. Su muerte, natural, tiene sabor a escape. Es imprescindible recordar el carácter contingente de su destino: por esos días, ardían los cuerpos de Giordano Bruno y Domenico Scandella.

\footnotetext{
84. Ibid., fol. 56 r.

85. Ibid., fol. 56 r.

86. Ibid., fol. 64 r. de la demonología radical en el imaginario hispánico.

88. Ibid., fol. 68 r.

89. Ibid., fol. $44 \mathrm{r}$.

90. Ibid., fol. $80 \mathrm{v}$.

91. Ibid., fol. 96 r.

92. Ibid., fol. 99 v. El subrayado es nuestro.

93. Ibid., fol. $116 \mathrm{v}$.
}

87. Ibid., fol. 64 v. Por primera vez se hace referencia al diablo, ratificando la escasa inserción 
IV. El profesor, fiel a su eco de devotio moderna, más preocupado por la pietas que por la doctrina, defendía la libre hermenéutica de las Sagradas Escrituras ${ }^{94}$. Así, se oponía al escolástico principio magister dixit, aquel que imponía a los doctores de la Iglesia como fuente de igual autoridad que la Biblia para referirse a cuestiones de fe. Nuestro héroe lo dijo sin matices: «él creerá lo que tiene la Escritura, y que de lo que dicen los santos no se le da nada ${ }^{95}$.

Más allá de la inevitable simpatía de esta declaración con nuestra ejercitada episteme cientifica, no está fuera de lugar sospechar acerca de la presencia de elementos en el seno de la estructura epistemológica del humanismo católico que habrían precipitado su caída en desgracia. De Certeau, por ejemplo, utilizando la categoría del no sin (nicht obne) de Heidegger, habla de una «estructura comunitaria» del lenguaje cristiano, en tanto «nadie es cristiano sin los otros», pues "una irreductible pluralidad de autoridades es la única que puede indicar la relación que cada una de ellas mantiene con lo que postula como "cristiana" ". En otras palabras, afirma que, como autoridad, ni el Papa, ni la Escritura, ni la tradición son suficientes; los otros le faltan, porque «su relación necesaria con otros hace y dice la índole de su relación con el Otro que lo autoriza. Aquí, el plural es la manifestación del sentido» ${ }^{96}$.

Evidentemente, Erasmo y Brozas habrían condenado enérgicamente esta definición de cristianismo. Según Bataillon, el humanismo erasmista aspiraba a restituir el mensaje cristiano en su auténtica pureza y desarrollar una suerte de filosofía de Cristo cuyos fines mundanos no eran más que «la alegría y la paz» ${ }^{97}$. Considerada esta definición, la contraposición entre ambas posturas es diáfana: al necesario diálogo colectivo y acumulativo del jesuita, el humanista oponía la philosophia Christi, una religión definitivamente íntima y singular que privilegiaba la rectitud moral por sobre la liturgia, con el fin de recuperar una pureza perdida.

Continuaba De Certeau:

el cuerpo escriturario no sería cristiano sin esa remisión a otros. El límite tiene una función permisiva. En cada espacio sincrónico y en el despliegue diacrónico, representa un papel de diferenciación que restaura continuamente la falta del otro, en la forma de la fe o de la caridad. [...] En consecuencia, no es posible aceptar las reducciones unitaristas. En el curso de la historia, por otra parte, se determinaron una a la otra, cuando, por ejemplo, el cristianismo fue reducido al privilegio de una letra escrituraria, o identificado con la palabra de un personaje eclesiástico, o bloqueado en un cuerpo institucional y doctrinal, o ahogado en lo indiferenciado totalitario de una "profundidad mistica"

94. C. M. N. Eire, op. cit., p. 33; A. Rabil, op. cit., pp. 99-114.

95. B. N. Ms. 12745 , fol. 56 r.

96. M. De Certeau, La faiblesse de croire, pp. 219-220. Subrayado en el original. Cf. M. Heidegger, «Temps et être», en L'endurance de la pensée. Pour saluer Jean Baufret, Paris, Plon, 1968, pp. 16-71.

97. M. Bataillon, Érasme et l'Espagne, p. 802. Subrayado en el original.

98. M. De Certeau, La faiblesse de croire, p. 221. Subrayado en el original. 
Y, como si no quedara clara la dimensión anti-cristiana de la exégesis humanista, proseguía algunas páginas más adelante:

\begin{abstract}
este encuentro directo entre el espiritu moderno y el lenguaje primitivo del espiritu cristiano es ante todo una liberación; es un matrimonio entre la ciencia contemporánea y el origen evangélico. De tal manera, la exégesis se saltea las meditaciones eclesiásticas. En el sentido quimico de la palabra, "aisla" la relación entre un texto (sagrado) y un lector (erudito). Finalmente, lo que produce, como en una fábrica, es lo que una práctica hace con su material. Pero de tal modo esa exégesis destruye el principio que las iglesias mantenian con derecho: una inserción colectiva en la historia presente ${ }^{99}$.
\end{abstract}

Tal vez haya aquí una huella para comprender la aún tibia pero incipiente disociación entre ciencia moderna y religión, que se haría más evidente en el siglo XVII ${ }^{100}$.

Retomando las premisas propuestas más arriba, puede pensarse que el discurso de Brozas se excluye de la gran narración cristiana, presentándose como una excepción superadora; se desentiende del «doble movimiento de amplificación y abstracción» de la narración originaria, y, al rechazar institucionalizarla, se niega a objetivar su fe. Sin embargo, es precisamente una objetivación separar a la fe de su existencia histórica, pues así, según la apreciación de la doctora O'Rourke Boyle, «theology is not a discipline of rigorous exploration into God, as in the scholastic questio, but a linguistic appropriation of the archetypal text ${ }^{101} . \mathrm{Si}$ De Certeau tiene razón, la aventura humanista que, como Brozas, mantuviera su fidelidad pública hacia la Santa Madre Iglesia pero conservara su objetiva ambición exegética de las Sagradas Escrituras y su rechazo a la tradición, estaba condenada al fracaso de sus posiciones políticas. Por eso, vale la pena recordar la respuesta del calificador Arce al reclamo del Brocense de que lo entendieran, más que creerle. Para Arce, «si se cree esta proposición, es grande herejía de los

99. Ibid., p. 258. Subrayado en el original.

100. Cf. M. Biagioli, Galileo, Courtier: The Practice of Science in the Culture of Absolutism, Chicago, Chicago University Press, 1993, passim; H. Kearney, Science and Change, 1500-1700, Londres, McGraw-Hill, 1971, passim; S. Shapin, Never Pure: Historical Studies of Science as if It Was Produced by People With Bodies, Situated in Time, Space, Culture, and Society, and Struggling for Credibility and Authority, Baltimore, The John Hopkins University Press, 2010, passim y The Scientific Revolution, Chicago, Chicago University Press, 1996, passim.

101. M. O'Rourke Boyle, Erasmus on Language and Method in Theology, Toronto, University of Toronto Press, 1977, p. 118. C. M. N. Eire también advierte el protagonismo del humanismo erasmista en la mutación semiótica renacentista: «Erasmus transcendentalism led him to promote a shift from concrete visual images to strictly verbal ones; from the sensual to the intellectual. The barrier between the visible and the invisible, according to Erasmus, could be most effectively crossed through the symbolic, representational power of words. In this way, language replaces the plastic arts as the medium of imagination. But as much as Erasmus separated the spiritual from the material, and as much as he interiorized religious expression, he never completely disembodied or silenced the life of faith. The spiritual is indeed invisible and interior, but it is certainly expressible. This is what keeps Erasmus from being a thoroughgoing spiritualist. Taking to heart the notion that human beings were the "image and likeness" of God principally in their invisible spiritual and intellectual capacities, Erasmus allowed for language to serve as the primary link between the human and the divine» (op. cit., p. 41). El subrayado es nuestro. 
gentiles y paganos maniqueos, que ninguna cosa quieren creer sino por razón natural, $y$ esto es decir que no ha de haber fe sobrenatural» ${ }^{102}$. M. A. Gillespie recuerda que Melanchthon le planteó una objeción similar a Erasmo: «while Erasmus rejected the most heroic forms of humanism, some wondered whether his emphasis on moral life as the key to salvation did not imply that Scripture and faith were unnecessary" ${ }^{103}$.

Sin embargo, la precisión de De Certeau no puede ser aplicada al humanismo erasmista porque éste nunca alcanzó el grado de entusiasmo bíblico de los protestantes, y no permaneció ajeno a su existencia histórica, en tanto combinaba, nuevamente según Gillespie, "the individualism of Italian humanism (devoid of its martial heroism) with the imitation of Christ (imitatio Christi) of the devotio moderna by means of a humanistic study that combined the study of pagan literature and Scripture within the Neoplatonic horizon of Origen, Jerome, and Augustine as well as Petrarch, Valla, and Pico» ${ }^{104}$. El mismo Erasmo reconocía la importancia de la «inserción colectiva en la historia presente» cuando, en medio de su desacuerdo soteriológico, objetó a Lutero su criterio unilateral de verdad -respaldado en la sola scriptura-preguntándose si era posible que todas las lecturas del texto sagrado a lo largo de la historia hubieran sido erradas. De este modo, el espíritu libre de Rotterdam tendía puentes con su Iglesia, pero, sobre todo, se insertaba él mismo en el tiempo, en la coyuntura ${ }^{105}$. Brozas, en cambio, se mostró más intransigente, considerando que, más allá de su utilización de los maestros paganos como fuentes magister dixit, nunca pareció demasiado dispuesto a reconciliarse con los doctores de la Iglesia, a pesar de sus declaraciones de obediencia ${ }^{106}$.

Ahora bien, el humanismo erasmista no es una risueña anomalía en la historia del cristianismo. Si bien se reconoce en la historia de este movimiento cultural que su denominador común, los studia humanitatis, implicaban una formación intelectual que enfatizaba más el estudio sistemático del lenguaje, la filosofía y

102. B. N. Ms. 12745, fol. 53 v. El subrayado es nuestro. En el argumento del funcionario inquisitorial, además, parece reproducirse la antigua advertencia de Agustín, una vez más en su De haresibus ad Quodvultdeum: "sed multum adiuvat cor fidele nosse quid credendum non sit, etiamsi disputandi facultate id refutare non possit " (epílogo, 3) y de la refutación bíblica de Isaías (7:9): «si non credideritis, non permanebitis». Respecto del lugar común epistemológico que planteaba la superioridad de la creencia por sobre el entendimiento, cf. M. H. Shank, "Unless You Believe, You Shall Not Understand": Logic, University and Society in Late Medieval Vienna, Philadelphia, Princeton University Press, 1988, passim.

103. M. A. Gillespie, op. cit., p. 96.

104. Ibid., p. 97.

105. A. J. Cappelletti, op. cit., p. 50.

106. Sólo un estudio más profundo permitirá definir la pertenencia o no del Brocense a la corriente escéptica que, desde los prolegómenos de la Edad Moderna, se constituía como un campo discursivo relativamente autónomo. Cf. M. Burnyeat, The Skeptical Tradition, Berkeley, University of California Press, 1983, passim; L. Febvre, Le problème de l'incroyance au XVI siècle. La religion de Rabelais, Paris, Michel Albin, 1942, passim; M. Gauna, Upwellings. First expressions of Unbelief in the Printed Literature of the French Renaissance, Salem, Associated University Presses, 1992, passim; R. Popkin, The History of Scepticism: from Savonarola to Bayle, Oxford, Oxford University Press, 2003, passim. 
la historia y menos la teología, el humanismo fue también la expresión de una conciencia de necesidad de reforma del cristianismo occidental como remedio de las tendencias atomizantes que amenazaban a la Europa bajomedieval. Por eso, hasta avanzado el siglo XVI, la palabra reforma tuvo un valor, si no positivo, al menos biensonante ${ }^{107}$. Serán los acontecimientos políticos los catalizadores del combate cultural emprendido por y contra el humanismo, que no pudo, no supo, no quiso, precipitar el cisma, y así se constituyó en objeto anatematizado ${ }^{108}$. Desde entonces, sin abierta ruptura, la supervivencia de lo disímil dentro del sistema hegemónico se volvería disrupción y amenaza ${ }^{109}$.

Si es cierto que «dadas las circunstancias españolas, era la Corona la principal instancia que podía contribuir con eficacia al movimiento humanístico», el cisma alemán, la Reforma radical y la revolución calvinista, al forzar la ruptura y contribuir a la inflación de las pretensiones de eliminación de la disidencia interna al interior de Europa, enajenaron al humanismo del mecenazgo del Estado ${ }^{110}$. En otras palabras, las últimas herejías que forjaron un cisma sustentable en la historia del cristianismo occidental, les religions prétendues réformées, expusieron peligrosamente a los humanistas españoles -relativamente a salvo durante la primera mitad del siglo en la corte de Carlos V (privilegio que empezó a resquebrajarse en 1527, cuando las furiosas invectivas enfrentadas en la Conferencia de Valladolid evidenciaron que un desequilibrio de fuerzas era inminente) - ante el fenomenal ascenso de zelotes y conservadores. Tal vez pueda aplicarse a Brozas el mismo juicio póstumo que Kamen dedicó a la frialdad de Erasmo, cuyo «error» habría sido tomar una visión demasiado intelectual de la verdad religiosa por su aparente incapacidad de comprender la ardiente sensibilidad frente a su fe de los protagonistas más representativos de la Era de la Reforma ${ }^{111}$. Tampoco -se podría agregar- pudieron algunos humanistas escapar a la obsesión por las postrimerías que arrastraba a Europa desde el comienzo de la expansión feudal y que llegaría al paroxismo en el siglo $\mathrm{XVI}^{112}$. La Corona española, por supuesto, no fue ajena a este proceso, sino

107. Cf. J. Lafaye, op. cit., pp. 308-326.

108. La diferencia entre cisma y herejía radica, según De Certeau, en que la segunda sólo existe cuando una posición mayoritaria tiene el poder de nombrar en su propio discurso y excluir como marginal a una formación disidente. Así, una autoridad sirve de marco de referencia al grupo mismo que se separa o que ella rechaza, mientras que el primero supone dos posiciones, ninguna de las cuales puede imponer a la otra la ley de su razón o la de su fuerza. (Le lieu de l'autre. Histoire religieuse et mystique, Paris, Seuil/Gallimard, 2005 -se cita a partir de la edición argentina: El lugar del otro. Historia religiosa y mística, trad. Víctor Goldstein, Buenos Aires, Katz, 2007, p. 30).

109. F. Campagne, Strix hispánica, p. 317. Cf. J. Kristeva, Pouvoirs de l'horreur. Essai sur l'abjection, Paris, Seuil, 1980, p. 4.

110. L. Gil, op. cit., p. 18.

111. H. Kamen, The Rise of Toleration, New York, McGraw-Hill, 1967 (se cita a partir de la edición española: Los caminos de la tolerancia, trad. Jaime Zarraluqui, Madrid, Guadarrama, 1967, p. 27).

112. Sobre la escatología cristiana del segundo milenio, cf. Frederic J. Baumgartner, Longing for the End. A History of Millenialism in Western Civilization, New York, Palgrave, 1999, pp. 63- 
más bien una pieza clave de la reconquista católica de la christianitas, como lo demostró, en el período que nos convoca, con su implacable espíritu de cruzada: en el exterior, lo manifestó a través de su entusiasta apoyo material a la Liga durante las últimas guerras de religión en Francia y en el audaz intento de invasión de las islas británicas; en el interior, mediante la brutal imposición de la ortodoxia tridentina y los numerosos mecanismos para convertir pacíficamente a sus propios cristianos ${ }^{113}$.

Por otra parte, el Santo Oficio supo aprovechar el flanco débil de los humanistas: según J. Pérez, el erasmismo nunca dejó de ser un movimiento intelectual elitista, naturalmente antipopular. Así, el Estado confesional habría logrado encauzar la tendencia del común a "expresar su religiosidad a través de representaciones fuertemente realistas» y su "recelo instintivo" hacia la elite cultural, cada vez más sospechosa de ser un vehículo de heterodoxia ${ }^{114}$. Además, la carta de la adiaphora, tan útil a los humanistas más radicales, que así justificaban su desprecio por muchos de los signos exteriores de la fe, podía ser también un argumento funcional a las pretensiones estatales de intervenir sobre los campos grises de la creencia ${ }^{115}$. Esto favorecería, en el corto plazo, la interrupción del proceso de alfabetización progresiva iniciado en el siglo XV y un afianzamiento del espectáculo como espacio de intermediación vertical entre las culturas ${ }^{116}$. El irenismo erasmista no tenía lugar en una comunidad confesional uniforme que, como todo proceso cultural hegemónico, sólo "comienza a ser operativo cuando manifiesta la diferenciación entre su discurso dominante y el de aquellos otros que, coetáneos o próximos, expresan discursos distintos, muchas veces rotos u ocluidos» ${ }^{117}$.

En el ocaso del siglo XVI, el éxito de la ortodoxia de corte filipino fue demasiado contundente como para descartar que la caída del humanismo erasmista en España (tan influyente en la corte del primer Austria) no hubiera respondido a su debilidad política y al ascenso de una cultura católica menos permisiva y más celosa de sus límites. Si bien la tristemente célebre Leyenda Negra merece una enérgica desmentida, y tienen razón quienes sostienen que la Inquisición no fue el único factor que contribuyó a frenar el desarrollo del humanismo clásico en la península ibérica, esto no impugna su rol decisivo en el clima de intolerancia que aplacó paulatinamente el espíritu renovador

100; N. R. C. Cohn, The Pursuit of the Millenium. Revolutionary Millenarians and Mystical Anarchists of the Middle Ages, Oxford, Oxford University Press, 1957, passim; D. Crouzet, Dieu en ses royaumes. Une histoire des guerres de religion, Paris, Champ Vallon, 2008, passim; Bernard Mc Ginn, Anti-Christ. Two Thousand Years of the Human Fascination with Evil, New York, Harper Collins, 1994, pp. 114-199; J. Taubes, Abendländische Eschatologie, Berlín, Matthes \& Seitz, 1947 (se cita a partir de la edición espańola: Escatología occidental, trad. Carola Pivetta, Madrid, Miño y Dávila, 2010, pp. 113-160).

113. Contreras, J. «Procesos culturales hegemónicos...», p. 330.

114. J. Pérez, «Reformas y heterodoxias. El erasmismo castellano», p. 119.

115. G. Remer, op. cit., pp. 140-141.

116. B. Bennassar, «Contrarreforma y repliegue cultural», pp. 142 y 166-168.

117. J. Contreras, «Procesos culturales hegemónicos...», p. 332. 
que había llevado a las letras españolas a su máximo esplendor ${ }^{118}$. Los Índices expurgatorios, los insistentes procesos judiciales, las esporádicas pero inclementes hogueras, el miedo, el «afán vigilante» y la eficacia con que el arma inquisitorial del Estado se entrometió en la vida cotidiana de los cristianos, obligan a considerarla como el instrumento central del catolicismo español del Siglo de Oro en su aspiración a defender el dogma extra ecclesiam nulla salus $^{119}$. Pareció, al menos, la condición que más cerca estuvo de domesticar al escurridizo Brocense.

118. Cf. R. García Cárcel, La leyenda negra. Historia y opinión, Madrid, Alianza, 1992, pp. 14-15. La expresión «leyenda negra» fue parida por J. Juderías (La leyenda negra, Madrid, Swan, 1986 (1914)).

119. Para matizar la romántica omnipotencia alguna vez atribuida al Santo Oficio, cabe citar el trabajo clásico de G. Henningsen («El "Banco de datos" del Santo Oficio. Las relaciones de causa de la Inquisición Española (1550-1700)», Boletín de la Real Academia de la Historia, vol. 174:3, sept-dic 1977, pp. 547-570), donde expone que entre 1550 y 1700 los tribunales de la corona de Aragón condenaron a la hoguera a 520 personas; y en Castilla, entre 1540 y 1660, la cifra es de 167 relajados en persona. Suman 687, es decir, sólo el 1,83 \% de los encausados por el Santo Oficio en dicho período fueron ejecutados en la hoguera. Por su parte, W. Monter, apoyándose en las conclusiones de Lea, desmiente el supuesto abuso de la tortura, afirmando que ésta era más común en los tribunales seculares que en los inquisitoriales. También afirma que el resultado más común ante el empleo de la tortura era la resistencia eficaz del reo (Frontiers of Heresy. The Spanish Inquisition from the Basque Lands to Sicily, Cambridge, Cambridge University Press, 1990 -se cita a partir de la edición española: La otra Inquisición. La Inquisición española en la Corona de Aragón, Navarra, el País Vasco y Sicilia, trad. Felipe Alcántara, Barcelona, Crítica, 1992, pp. 96-97). Respecto del «afán vigilante», cf. W. Thomas, op. cit., p. 79. 